\title{
Palaeoecological, archaeological and historical data and the making of Devon landscapes. I. The Blackdown Hills
}

\author{
ANTONY G. BROWN, CHARLOTTE HAWKINS, LUCY RYDER, SEAN HAWKEN, FRANCES GRIFFITH AND \\ JACKIE HATTON
}

BOREAS

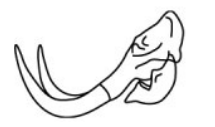

Brown, A. G., Hawkins, C., Ryder, L., Hawken, S., Griffith, F. \& Hatton, J.: Palaeoecological, archaeological and historical data and the making of Devon landscapes. I. The Blackdown Hills. Boreas. 10.1111/bor.12074. ISSN 0300-9483.

This paper presents the first systematic study of the vegetation history of a range of low hills in SW England, UK, lying between more researched fenlands and uplands. After the palaeoecological sites were located bespoke archaeological, historical and documentary studies of the surrounding landscape were undertaken specifically to inform palynological interpretation at each site. The region has a distinctive archaeology with late Mesolithic tool scatters, some evidence of early Neolithic agriculture, many Bronze Age funerary monuments and RomanoBritish iron-working. Historical studies have suggested that the present landscape pattern is largely early Medieval. However, the pollen evidence suggests a significantly different Holocene vegetation history in comparison with other areas in lowland England, with evidence of incomplete forest clearance in later-Prehistory (Bronze-Iron Age). Woodland persistence on steep, but poorly drained, slopes, was probably due to the unsuitability of these areas for mixed farming. Instead they may have been under woodland management (e.g. coppicing) associated with the iron-working industry. Data from two of the sites also suggest that later Iron Age and Romano-British impact may have been geographically restricted. The documented Medieval land management that maintained the patchwork of small fields, woods and heathlands had its origins in later Prehistory, but there is also evidence of landscape change in the 6th-9th centuries AD. We conclude that the Blackdown Hills area was one of many 'distinctive subregions', which due to a combination of edaphic, topographic and cultural factors could qualify as an eco-cultural region or 'pays'. It is argued that the use of such eco-culturally distinctive regions or pays can provide a spatial and archaeological framework for palaeoecology, which has implications for landscape research, designation and heritage management.

Antony G. Brown (Tony.Brown@soton.ac.uk), Palaeoeenvironmental Laboratory, University of Southampton (PLUS), Shackleton Building, Highfields Campus, Southampton SO17 1BJ, UK; Charlotte Hawkins, Sean Hawken and Jackie Hatton, Department of Geography, University of Exeter, Exeter EX4 1RJ, UK, Lucy Ryder, Department of History and Archaeology, University of Chester, Parkgate Road, Chester CH1 4BJ, UK; Frances Griffith, Historic Environment Service, Devon County Council, County Hall, Exeter EX2 4QW, UK; received 5th February 2013, accepted 31st January 2014.

Our knowledge of the vegetation history of Europe is heavily biased to upland and lowland mires and lakes, yet the majority of the agricultural population of Europe must always have been located in catchment areas between these topographic extremes. The data presented are the result of an archaeological study of lowland landscapes in Devon, investigated as part of the Heritage Lottery-funded Community Landscapes Project (CLP; Brown et al. 2004). The CLP involved targeted field survey (by both professionals and amateurs), documentary analyses, folklore and palaeoecology. The area covered in this paper is also of wider interest as it appears to straddle a deep-time landscape boundary with the 'central region' of England to the east dominated by medieval villages, Roman villas and large Iron Age hillforts and to the west a region with dispersed medieval settlement patterns, lack of Romanization and smaller Iron Age enclosed settlements (Rippon 2012; Rippon et al. 2013).

At least 78 pollen diagrams are published from Devon and western Somerset alone but 64 of these are from the upland areas of Dartmoor (44) and Exmoor (20) and all the remaining diagrams are either coastal and/or very limited in their temporal coverage. The comparison of the results of this intermediate inland area with the well-researched uplands of Dartmoor and Exmoor provide the most complete coverage of any region in Europe (at 1 diagram $100 \mathrm{~km}^{-2}$ over $6707 \mathrm{~km}^{2}$ ) and permit the identification of eco-cultural regions or pays - a term of French origin and associated with Paul Vidal de la Blache that is being increasingly used by British and European landscape historians (De la Blache 1918; Turner 2007; Rippon et al. 2013). The recognition of such regions can also now contribute to the planning process in the UK through the mapping of 'historic character', a process that has been implemented by English Heritage (for Devon see Turner 2005). In addition to the palaeoecological studies an archaeological survey was undertaken around each palaeoecological site and in some cases geophysical survey and excavation. This was an attempt to redress the common problem of a spatial mismatch between archaeological sites and palaeoecological sites typical in Europe (Odgaard 1992; Skinner \& Brown 1999; Fyfe \& Woodbridge 2012). This paper offers both an interpretation of the pollen evidence as a contribution to the study of pays and a consideration of the methodology by which the study of small-scale palynological sources can be interpreted as part of landscape reconstruction. 
The primary aim of this paper was to examine the vegetation history of an intermediate agricultural zone of a region which has a well-known upland vegetation history and in doing so, establish the homogeneity of vegetation reconstructions at the regional scale. A secondary aim was to explore the inferential value of palynological data through site-specific archaeological and historical investigations.

\section{The Blackdown Hills}

The Blackdown Hills, which are an uplifted plateau of Mesozoic strata, cover an area of $350 \mathrm{~km}^{2}$ to a plateau height of 250-270 $\mathrm{m}$ a.s.1. The plateau gently dips to the east with scarp faces and is incised by steep-sided valleys (slopes $>1: 4$ ) known as 'combes'. The geology is Upper Greensand and clay-with-flints and this makes the soils base deficient and stony but cultivatable on the plateau. The topography and geology control the occurrence and distribution of palaeoecological sites, which are either valley-side spring mires formed on the spring-line caused by impermeable beds in the Upper Greensand, or narrow valley mires in the combe bottoms. As the major aquifer, the Greensand, lies beneath the Tertiary clay-with-flints, which has moderate fertility, the mires are acidic but mesotrophic to eutrophic. The predominant land use is semipermanent grassland or 'leys' (temporary grassland), in a pattern of long grassland leys interspersed with episodes of cultivation which produces neither good earthwork survival nor regular opportunities for fieldwalking or aerial reconnaissance for cropmarks. The Blackdown Hills were designated as an Area of Outstanding Natural Beauty in 1991 under UK planning law (1946) despite relatively little being known about their landscape history.

The Blackdown Hills also form a landscape and administrative boundary between the Somerset Lowlands to the north, the Downlands of Wessex to the east, and Devon heathlands to the west. As late as the Post-Medieval period the hills were regarded as 'marginal', 'wild' and 'sinister' in local folklore, which is believed to have Medieval origins (Franklin 2006). The hills have until recently been poorly covered in regional archaeological surveys (e.g. Todd 1987; Cunliffe 1993); however, research has suggested a distinctive archaeology with late Mesolithic lithic scatters, early Neolithic agriculture, Bronze Age monuments and RomanoBritish and Saxon iron-working being some of the distinctive elements (Berridge 1985; Griffith 1994; Griffith \& Weddell 1996; Webster 2008). The archaeologically difficult nature of the land use is reflected in the Historic Environment Record (HER), where the evidence base at the time of the project was dominated by some substantial earthworks such as hillforts, relict field boundaries, and the abundant traces of former iron- working. The most abundant records were of Medieval and Post-Medieval farmhouses and mill works. The relative absence of recent development means that the area has not seen modern rescue excavation on a scale comparable with the excavations along the modern A30 to the southwest of the study area (Fig. 1; Fitzpatrick et al. 1999) or elsewhere in SW England (Webster 2008). Despite the relatively low amount of arable land, locally based fieldwalking over a number of years has shown a surprisingly high level of Mesolithic activity (Berridge 1985) and later Mesolithic flints are also known from Hembury Hill fort (Fig. 1; Whittle 1977; Berridge 1986). The area has been the focus of local archaeological investigations such as Silvester \& Bidwell (1984), and also wider investigations into the iron-working and whetstone industries (Stanes \& Edwards 1993; Griffith \& Weddell 1996). The current landscape is characterized by small irregular pastoral fields with some larger fields resulting from PostMedieval enclosure of common land on the Greensand plateau. Indeed the area contains some of the latest 'Parliamentary enclosures' in Devon: Stockland Hill was not enclosed from heath until 1864, and Beacon Hill, Upottery, not until 1874 (Griffith 1988). Irregular field systems are also visible in the Luppitt Valley and there appears to have been relatively little re-organization of the landscape as a result of the mechanization of agriculture in the 18th century. Prior to this study only a short pollen diagram covering the first millennium $\mathrm{AD}$ was published from a lens of peat in a valley at Aller near Stockland (Hatton \& Caseldine 1991).

\section{The study sites and methods}

Sites were identified from small peatlands within these agricultural landscapes using aerial photographs and historic maps (Hawkins 2005). The four sites selected at Bywood, Greenway Lane, Middleton and Bolham (Fig. 1) are all small $(<1$ ha, see Table 1) valley or spring mires except Bolham, which is a small palaeochannel on a narrow flood-plain. Site meta-data are given in Table 1 including off-site vegetation and current land use. As the sites are all very small, with diameters $<130 \mathrm{~m}$ and within closed basins, a strong representation of the local and extra-local vegetation within a patchy ecological landscape would be expected (Jacobsen \& Bradshaw 1980; Sugita 1994), especially in cultural landscapes (Overland \& Hjelle 2009). Modelling has supported a 'relevant source area of pollen' (RSAP sensu Sugita 1994) for small sites (25-250 m in diameter) of between 1000-3000 $\mathrm{m}$ and for sites at the smaller end of this range the RSAP is likely to be under $2000 \mathrm{~m}$ (Hellman et al. 2009). An additional factor with these shallow peat sites is the possibility of erosion, including bog bursts/slips and reworking. Both 
Fig. 1. The Blackdown Hills and location of the sites used in this study with inset of SW England showing areas from which pollen diagrams have been produced and the four study areas investigated as part of the Community Landscape Project.

Around each site is a $1 \mathrm{~km}$ radius, which, given the small sizes of the sites would probably be the source for $90 \%$ of the pollen (all local and extra-local pollen). Note that in all cases this area reaches to the Blackdown Hills plateau.

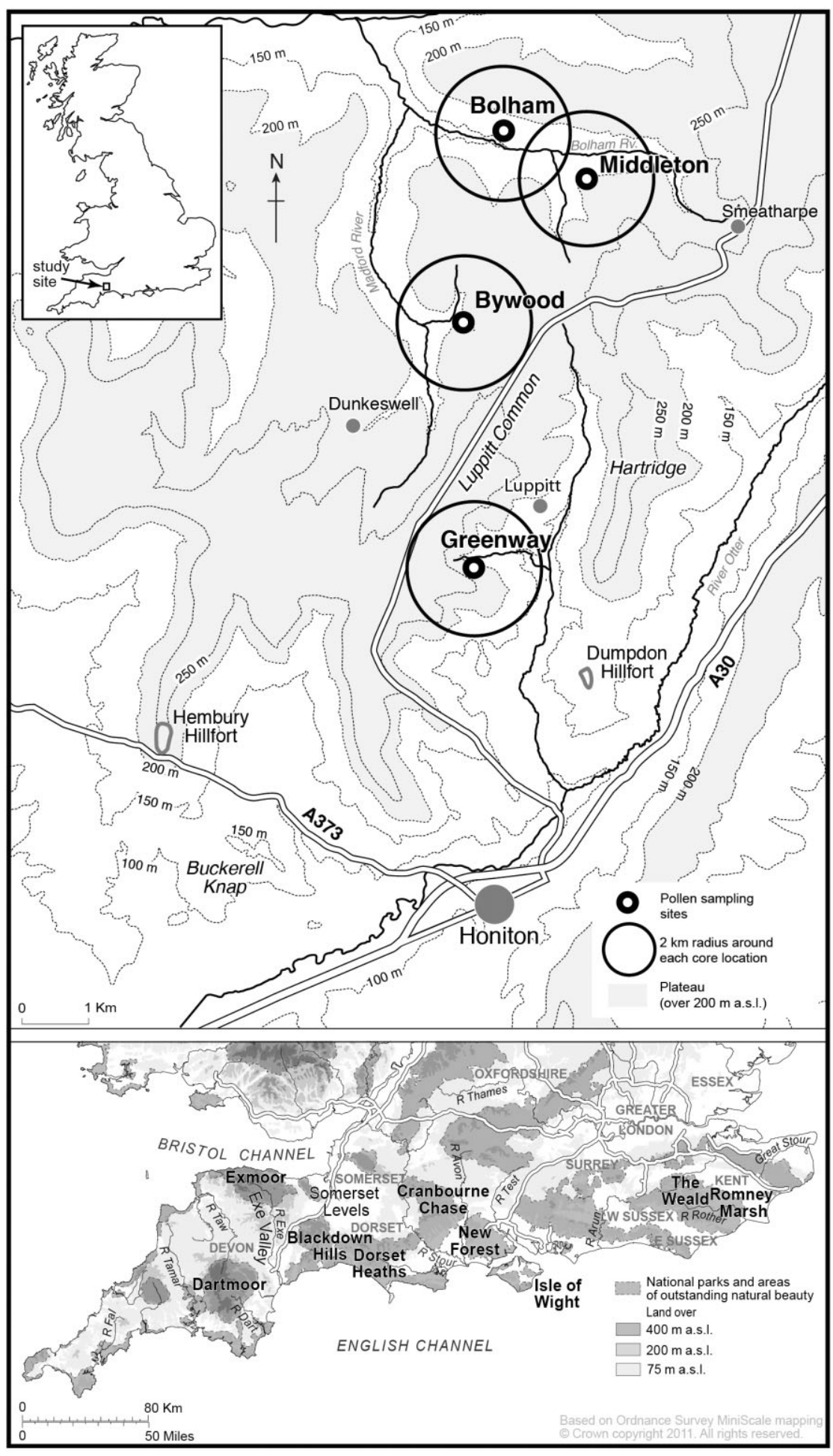

\section{Palaeoecological methods}

bon dates (Table 2) and both Bolham and Middleton have hiatuses. Whilst this affects the chronology and resolution of such sites through low accumulation rates and temporal gaps, the pollen input to such small wetlands is still overwhelmingly of local origin (Bunting 2008).
Sediment was described from cores along transects (Fig. 2) using the standard Troels-Smith system modified by Aaby \& Berglund (1986). Monolith tins were the preferred method of sampling but at some sites a fixed chamber (Russian) corer was used. Sediment for loss- 
Table 1. Site details, on-site vegetation and pollen catchment area.

\begin{tabular}{llllll}
\hline Site & Location & $\begin{array}{l}\text { Altitude } \\
(\mathrm{m} \text { a.s.1.) }\end{array}$ & $\begin{array}{l}\text { Size } \\
(\mathrm{m})\end{array}$ & Pollen catchment area & Dominant on-site vegetation \\
\hline Bywood & ST 15750955 & 200 & $90 \times 20$ & Plateau edge and upper steep slopes & $\begin{array}{l}\text { Poaceae, Carex paniculata, Juncus, Typha } \\
\text { angustifolia, Cirsium palustre, Filipendula } \\
\text { ulmaria, Potentilla palustris, Shagnum spp. } \\
\text { Preenway }\end{array}$ \\
Middleton & ST 16080563 & 205 & $90 \times 55$ & Plateau edge slope and spring & $\begin{array}{l}\text { Parex, Filipendula ulmaria, } \\
\text { Galium, Schrophularia and Equisetum }\end{array}$ \\
Bolham 17601160 & 190 & $95 \times 300$ & Valley-side slope and spring & $\begin{array}{l}\text { Poaceae, Carex, Danthonia decumbens, Luzula, } \\
\text { Erica tetralix, Ulex } \\
\text { Poa trivialis, Agrostis tenius, Ranunculus acris, } \\
\text { Caltha palustris, Lychnis flos-cuculi, Rumex, } \\
\text { Narthecium ossifragum, Alnus glutinosa }\end{array}$ \\
\hline
\end{tabular}

on-ignition (LOI) was oven dried overnight and burnt at $550^{\circ} \mathrm{C}$ for $4 \mathrm{~h}$ (Heiri et al. 2001). Cores were subsampled at $2-\mathrm{cm}$ intervals for pollen analysis. Sample size was $1 \mathrm{~cm}^{3}$ and samples were prepared following a chemical method adapted from Moore et al. (1991). Exotic spore tablets were added to each sample to determine the pollen concentration and the processed samples were mounted in silicon oil and examined at $\times 500$ magnification using a Leitz Dialux microscope. Small, difficult grains and cerealia were identified at $\times 1000$ magnification. The identification of pollen grains was made using the Exeter University pollen reference collection and the key in Moore et al. (1991) and Andrew (1984). Pollen nomenclature was adapted from Bennett (1994). A minimum of 500 total land pollen (TLP, excluding only aquatics and spores) grains were counted for each sample, although this was not always possible at Bolham where a reduced count of 200 grains (TLP) was used because of poor preser- vation and low pollen concentrations. The pollen data are expressed in percentage diagrams created using the computer program Tilia (Grimm 1988). Diagrams were then divided into local pollen assemblage zones (PAZ) by eye. All micro-charcoal fragments visible on the pollen slides were counted and expressed as particles $\mathrm{cm}^{-3}$. Due to uniformly high degrees of humification the sites were radiocarbon dated using accelerator mass spectrometry (AMS) ${ }^{14} \mathrm{C}$ of peat with one exception (Beta-177885), and care was taken to avoid possible sources of contamination of radiocarbon dates including the penetration of older sediment by younger roots. Nineteen samples for radiocarbon dating were submitted to the Beta Analytic Laboratory, Florida, USA. Calibration of the radiocarbon dates used the IntCal 04 (Stuiver \& Reimer 1993). Dates included on the pollen diagrams are expressed as uncalibrated BP whereas calibrated ages expressed as $\mathrm{AD} / \mathrm{BC}$ are provided in the Discussion and in Table 2.

Table 2. Radiocarbon dates from the four sites.

\begin{tabular}{|c|c|c|c|c|c|c|}
\hline $\begin{array}{l}\text { Site and } \\
\text { samples }\end{array}$ & Lab no. & $\begin{array}{l}\text { Depth } \\
\text { (cm) }\end{array}$ & Material dated & $\begin{array}{l}\text { Measured } \\
\text { age (a BP) }\end{array}$ & $\begin{array}{l}{ }^{13} \mathrm{C} /{ }^{12} \mathrm{C} \\
(\% 0)\end{array}$ & $\begin{array}{l}\text { Calibrated } \\
\text { age }(2 \sigma)\end{array}$ \\
\hline Bywood & $\begin{array}{l}\text { Beta-177878 } \\
\text { Beta-177881 } \\
\text { Beta-177879 } \\
\text { Beta-177880 } \\
\text { Beta-124989 } \\
\text { Beta-124990 }\end{array}$ & $\begin{array}{c}16-18 \\
39-40 \\
54-56 \\
74-77 \\
72-80 \\
162-172\end{array}$ & $\begin{array}{l}\text { Humified herbaceous }(T h) \text { peat } \\
\text { Humified herbaceous (Th) peat } \\
\text { Humified herbaceous (Th) peat } \\
\text { Humified herbaceous (Th) peat } \\
\text { Humified herbaceous (Th) peat } \\
\text { Humified herbaceous (Th) peat }\end{array}$ & $\begin{array}{c}640 \pm 50 \\
990 \pm 50 \\
2070 \pm 50 \\
2280 \pm 50 \\
1020 \pm 100 \\
2980 \pm 80\end{array}$ & $\begin{array}{l}-28.9 \\
-28.1 \\
-28.7 \\
-28.4 \\
-25.0 \\
-25.0\end{array}$ & $\begin{array}{l}\text { AD } 1280-1410 \\
\text { AD } 960-1180 \\
\text { AD } 200-40 \text { BC } \\
420-180 \text { BC } \\
\text { AD } 800-1235 \\
1410-940 \text { BC }\end{array}$ \\
\hline Greenway & $\begin{array}{l}\text { Beta-177882 } \\
\text { Beta-177883 } \\
\text { Beta-177884 } \\
\text { Beta-177885 }\end{array}$ & $\begin{array}{l}28-31 \\
40-42 \\
59-62 \\
70-74\end{array}$ & $\begin{array}{l}\text { Humified }(S h) \text { peat with clay } \\
\text { Humified }(S h) \text { peat with clay } \\
\text { Humified }(S h) \text { peat with clay } \\
\text { Wood }\end{array}$ & $\begin{array}{l}2940 \pm 60 \\
3610 \pm 70 \\
4070 \pm 70 \\
4520 \pm 60\end{array}$ & $\begin{array}{l}-29.0 \\
-28.9 \\
-29.4 \\
-26.6\end{array}$ & $\begin{array}{l}1300-870 \mathrm{BC} \\
2140-1760 \mathrm{BC} \\
2880-2460 \mathrm{BC} \\
3370-3020 \mathrm{BC}\end{array}$ \\
\hline Middleton & $\begin{array}{l}\text { Beta-177887 } \\
\text { Beta-177888 } \\
\text { Beta-177889 } \\
\text { Beta-17890 }\end{array}$ & $\begin{array}{c}38-40 \\
54-56 \\
94-96 \\
107-110\end{array}$ & $\begin{array}{l}\text { Humified herbaceous }(T h) \text { peat } \\
\text { Humified herbaceous }(T h) \text { peat } \\
\text { Humified herbaceous }(T h) \text { peat } \\
\text { Humified herbaceous }(T h) \text { peat }\end{array}$ & $\begin{array}{r}630 \pm 70 \\
1050 \pm 70 \\
1320 \pm 70 \\
4070 \pm 70\end{array}$ & $\begin{array}{l}-26.9 \\
-27.2 \\
-28.2 \\
-29.3\end{array}$ & $\begin{array}{l}\text { AD } 1270-1430 \\
\text { AD } 870-1160 \\
\text { AD } 620-880 \\
2880-2460 \text { BC }\end{array}$ \\
\hline Bolham & $\begin{array}{l}\text { Beta-182713 } \\
\text { Beta-182712 } \\
\text { Beta-182711 } \\
\text { Beta-182710 } \\
\text { Beta-182709 }\end{array}$ & $\begin{array}{c}41-44 \\
71-74 \\
107-110 \\
128-130 \\
142-146\end{array}$ & $\begin{array}{l}\text { Herbaceous peat }(T h) \text { with clay } \\
\text { Herbaceous peat }(T h) \text { with clay } \\
\text { Herbaceous peat }(T h) \text { with clay } \\
\text { Herbaceous peat }(T h) \text { with clay } \\
\text { Herbaceous peat }(T h) \text { with clay }\end{array}$ & $\begin{array}{r}290 \pm 60 \\
860 \pm 70 \\
5070 \pm 70 \\
9900 \pm 70 \\
7890 \pm 90\end{array}$ & $\begin{array}{l}-28.2 \\
-28.2 \\
-27.9 \\
-28.4 \\
-28.0\end{array}$ & $\begin{array}{l}\text { AD } 1455-1675 \\
\text { AD } 1020-1285 \\
4050-3650 \text { BC } \\
9605-9235 \text { BC } \\
7055-6480 \text { BC }\end{array}$ \\
\hline
\end{tabular}


Fig. 2. The primary long-sectional site stratigraphy of each site with the location of the core used for pollen analysis indicated. A. Bywood. B. Greenway. C. Middleton. D. Bolham.

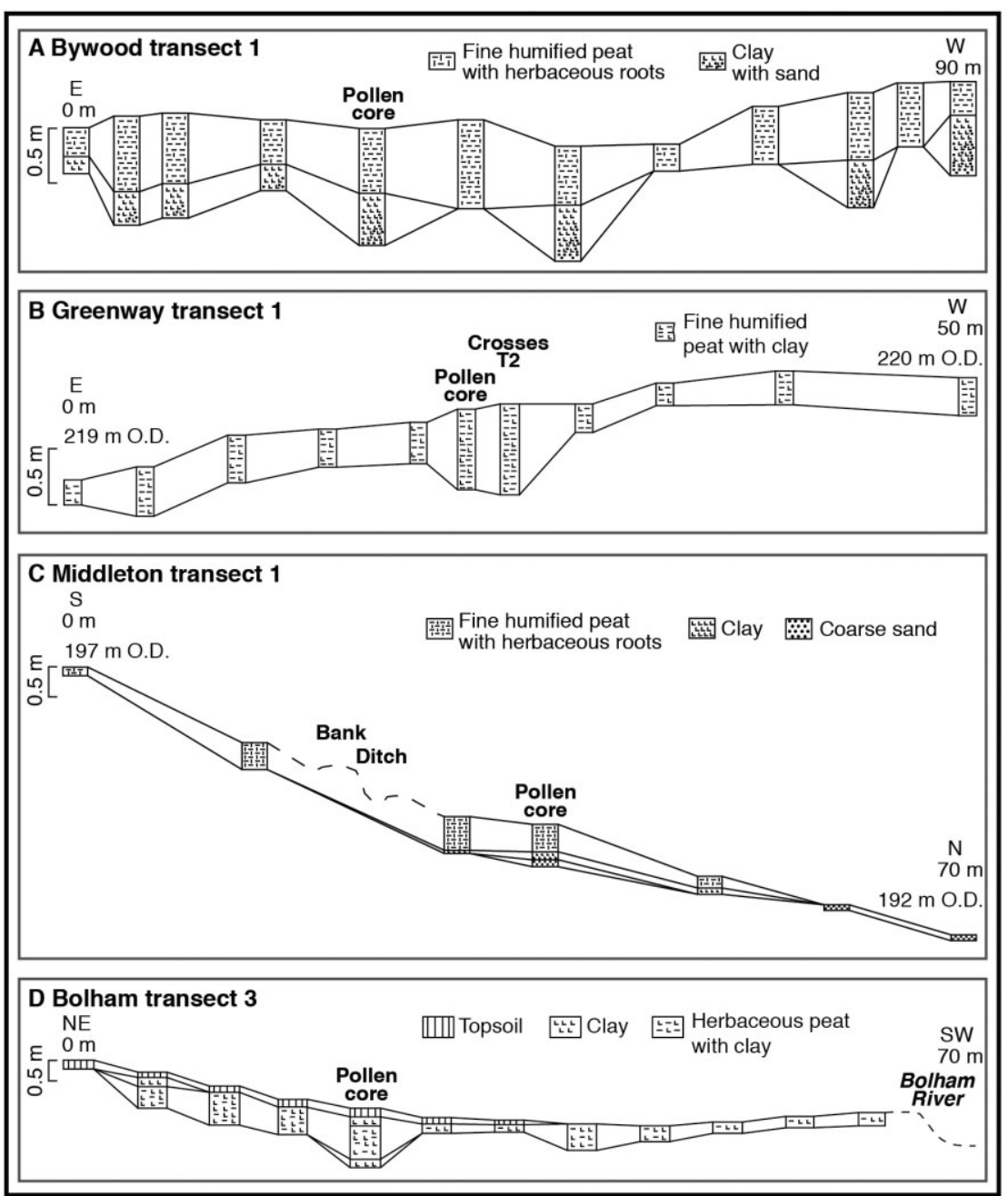

\section{Archaeological methods}

A desk-based assessment using the Devon HER of all archaeology within a $2 \mathrm{~km}$ radius of each of the pollen sites was undertaken (Fig. 3). This radius was chosen as it corresponded with and slightly exceeded the effective pollen source areas for such small sites. It is recognized that this radius is larger than the predicted pollen catchment area (Table 1); however, changes in the vegetation of the pollen catchment area may derive from humans based just outside the RSAP. The archaeological data were recorded in a database and on 1:10000 maps of each study area and reflect land use within and surrounding the local and extra-local pollen source area. This approach also involved an extensive literature review, and local history groups who were particularly useful in providing local documentary evidence of land use change. The survey of documentary evidence included collecting Domesday records for each manor (where available) and records held in county archives at the Westcountry Studies Library, Exeter. The Domesday book was the result of a remarkably com- prehensive survey of most of England and parts of Wales undertaken by in AD 1086 by William I of England (William the Conqueror). Tithe (taxation) apportionments from the 1840s Tithe Map were also recorded and provided a useful record of land ownership, land use, field names (which can often be archaeologically illuminating) and the landscape character of each Parish before the introduction of mechanized farming. There are limitations associated with the use of documentary evidence for landscape change and land use history; for example, Domesday entries record the name but not the location of each manor, and thus this has to be inferred from place names and manorial records. Inferred Domesday manorial land use was compared to the land use suggested by the pollen diagrams. The 1840s Tithe Map, was used to show areas of potential arable cultivation through the shape of field boundaries, field names and land use given in the Apportionments.

Archaeological records lodged in the HER, which were gathered together from a multiplicity of sources, vary greatly in detail and accuracy depending largely 


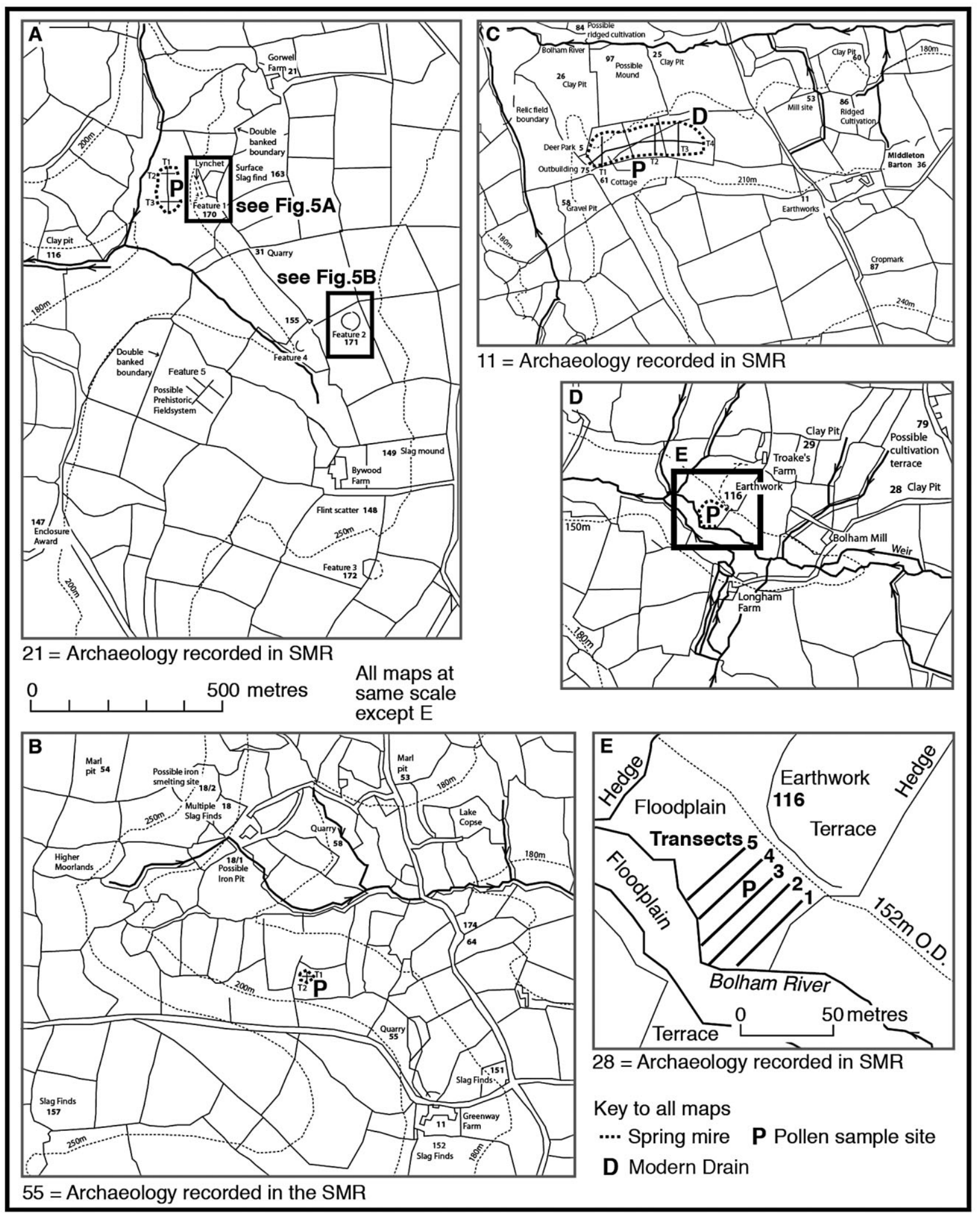

Fig. 3. The area around each palaeoecological site with archaeological sites from the Sites and Monuments Record (SMR) and surveyed archaeological features. A. Bywood. B. Greenway. C. Middleton. D. Bolham. E. Inset of Bolham flood-plain. 
on the interpretation of the observer. Many records are based on interpretations from aerial photographs and are thus in general undated. In the absence of secure dating and the frequent location of sites to an accuracy of no more than a $100 \mathrm{~m}$ square the integration of such data with information from pollen analysis is difficult. The Devon HER is a record of known archaeology in a particular area and thus is likely to have higher quality evidence for areas that have been the subject of intensive research or rescue excavations. The study areas were chosen because there had been little or no fieldwork undertaken compared with other areas of Devon. In the absence of detailed archaeological records the archaeological study areas (Fig. 3) were subject to noninvasive survey and fieldwork to identify any unrecorded archaeology. Volunteers surveyed relict field boundaries and features and the results were drawn up by CLP. Volunteers undertook intensive field survey of the archaeology at Bywood Farm, formerly part of the Dunkeswell Abbey estate (including a small-scale excavation and a watching brief, Fig. 3), the earthworks at Bushy Knap (Fig. 1) and Buckerell Knap, and the relict standing buildings Jacob's City (a Post-Medieval squatter settlement).

\section{Results: palaeoecology and archaeology}

\section{Bywood: palaeoecological results}

The radiocarbon dates (Table 2) indicate peat initiation in the Iron Age $c$. 420-180 BC and continued accumulation through the Romano-British, Post-Roman and Medieval periods. An age reversal between $72-80 \mathrm{~cm}$ (Beta-124989) and 162-172 cm (Beta-124990) along with a reduction in LOI suggests an input of pedogenic carbon associated with soil erosion.

The pollen diagram was divided into three zones (Fig. 4). Tree pollen, particularly Betula, Quercus and Corylus, comprise over $70 \%$ of the TLP in BW1. The woodland under-storey is represented by Lonicera, Pteridium, Pteropsida and Polypodium, whereas the presence of species-rich grassland is indicated by high quantities of Poaceae, Lactuceae and Brassicaceae taxa. Tree pollen curves increase simultaneously with a decline in grassland and herbaceous taxa at the BW1a/1b boundary. The appearance of low trees/shrub species such as Ilex aquifolium and woody climbers such as Hedera helix, and Lonicera with the continued presence of heliophilous herbs suggests that woodland was more open with grassland. However, trees continue to dominate until a sharp decline in BW2a accompanied by a rapid rise in Poaceae and herbaceous taxa. The quantities of herb taxa, for example Centaurea nigra, suggest that lightly grazed wet pasture occupied the wetland fringe as heavy grazing prevent herbaceous species from flowering (Grime et al. 1988; Groenman-van-Waateringe 1993). The steep rise in herbaceous pollen curves in the diagram at the BW1b/ BW2a boundary suggests that grassland dominated the largely open landscape. However, the appearance of cereal pollen above $50 \mathrm{~cm}$ suggests that arable cultivation also took place in the immediate vicinity of the mire. The pollen diagram continues to be dominated by grasses and herbaceous taxa until the BW2a/BW2b boundary, indicating that the landscape was at least partially open. There is little change in the diagram in BW2 but a rise in woodland taxa above $32 \mathrm{~cm}$ suggests woodland recovery. High levels of woodland taxa continued but in the upper levels of the diagram (BW3b) a decline in tree and heath pollen types occurs simultaneously with a rise in grasses and herb taxa and indicates that the Post-Medieval landscape was more open at Bywood.

\section{Bywood: archaeological and historical results}

Intensive archaeological investigation and small-scale excavation revealed Late Iron Age-Romano British enclosures, Romano-British iron-workings, relict Medieval field systems and a deserted Post-Medieval building platform all within $500 \mathrm{~m}$ of the pollen core location. Prehistoric activity is demonstrated by a flint scatter (Table S1, Fig. 3), whereas early Medieval activity is demonstrated by a radiocarbon date of 664-889 $\mathrm{AD}$ (Table S1) from an iron-slag pile close to the mire (Griffith \& Weddell 1996; Wiecken 2004). Ironworking, which is known from the Blackdown Hills by the very early Roman or the late Iron Age period, was also extensive during the early Medieval period with documentary sources indicating that by AD 1238 the Abbey of Dunkeswell controlled part of the industry (Summerson 1985; Griffith \& Weddell 1996). The land at Bywood was given to the Abbey as part of an agreement with Richard de Hinton, as listed in the Feet of Fines in AD 1244. Slag finds have been found $500 \mathrm{~m}$ east of the bog (Table S1) and has also been incorporated into a small building in the field in which Feature 2 is situated (Fig. 5). Evidence of Roman iron-working consisted of furnace lining and slag indicative of bloomery technology and charcoal produced radiocarbon dates of 10 BC to AD 330 and AD 70-420 (Wieken 2004). Field survey revealed a subcircular enclosure and geophysical survey revealed a D-shaped enclosure, possibly of late Prehistoric date. Other discoveries included two lynchets, a building platform, probably for a building recorded on the Tithe Map, and relict field boundaries all within $200 \mathrm{~m}$ of the mire (Feature 1). Two lynchets were also recorded on the hilltop, one of which underlies a current field boundary indicating pre-enclosure cultivation. The field boundary directly to the northwest of Feature 5 could have early Saxon origins because it is very wide, double banked and more substantial than other field boundaries-in order to keep woodland animals away from arable land. The semicir- 

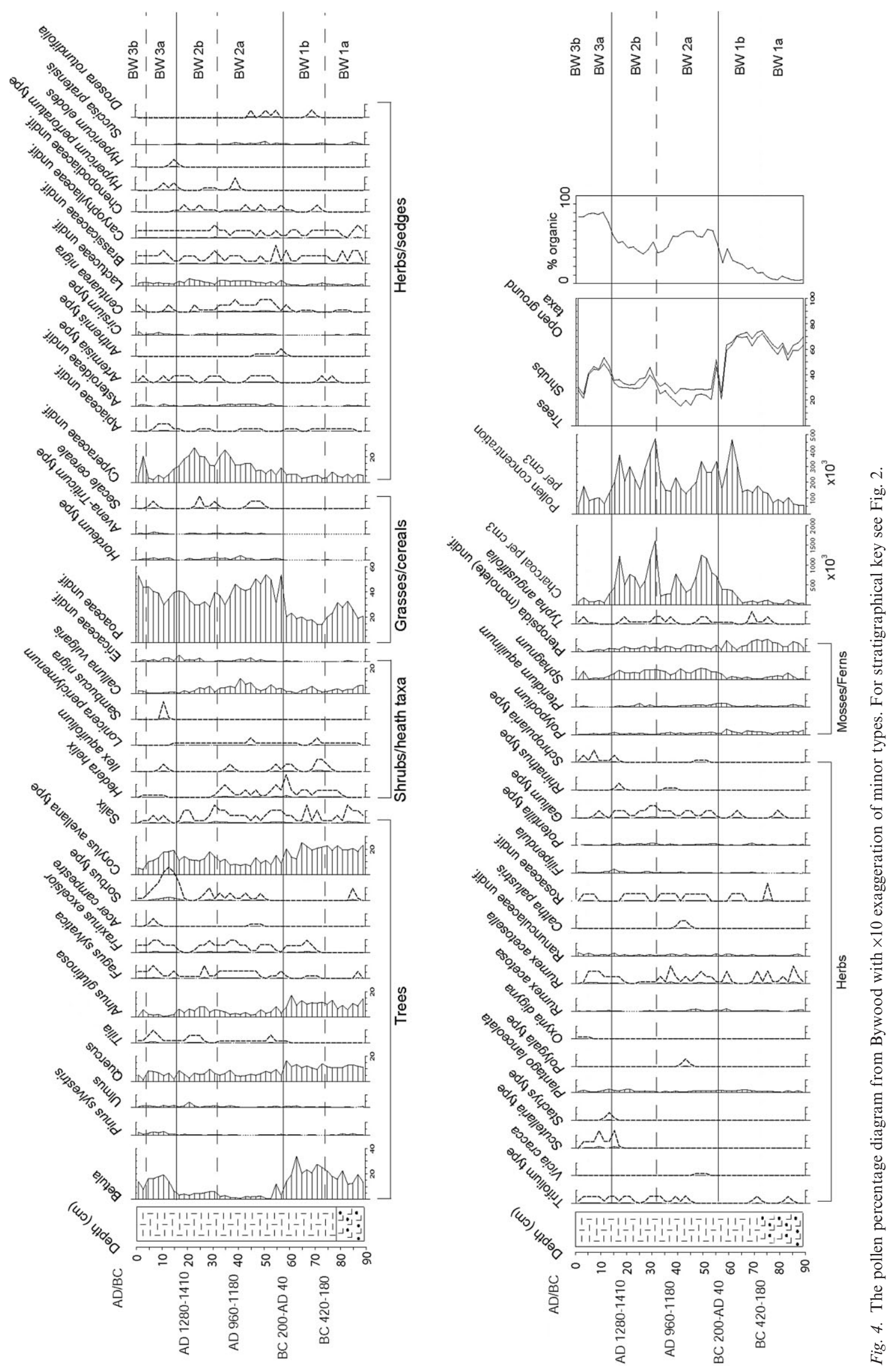
Fig. 5. Surveyed earthworks (enclosure and platforms) at Bywood Farm. A is feature 2 (HER no. 171) and B is feature 1 (HER no. 170).

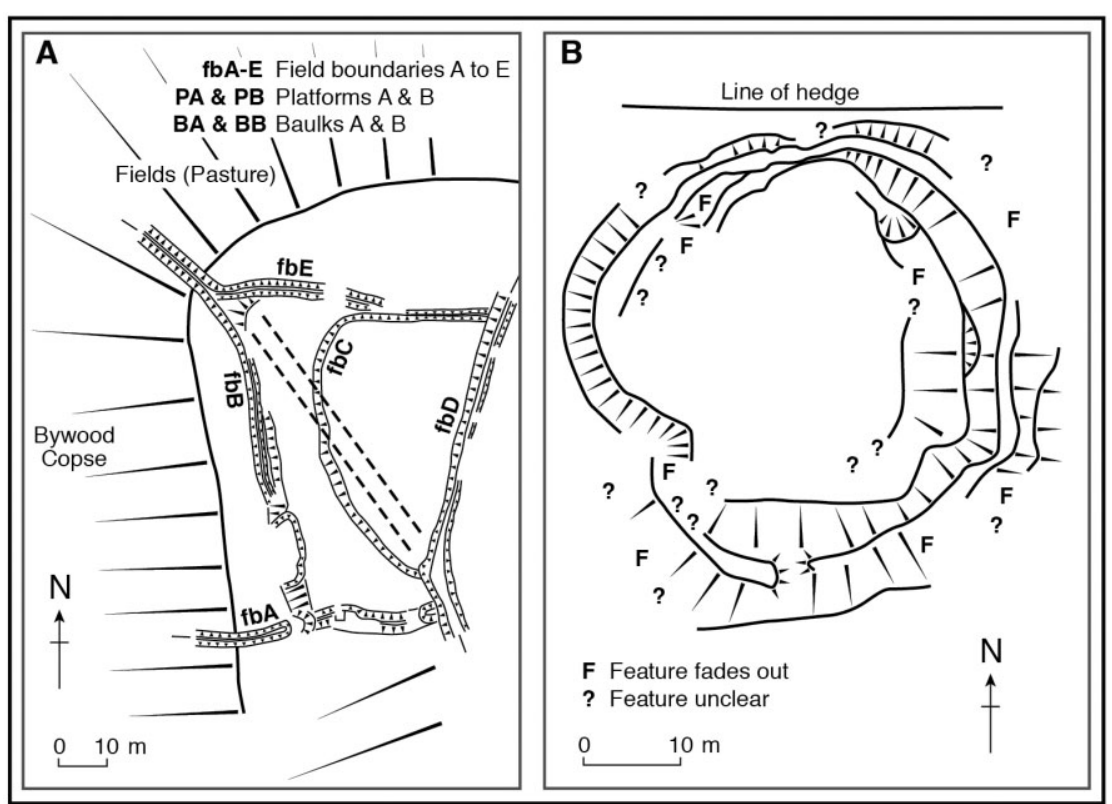

cular field to the immediate west of the field bank with less substantial boundaries probably represents enclosure of woodland. The manor of Bywood is recorded as 'Biuda' in Domesday, and 'Bywode' in the 13th Century Feet of Fines for AD 1244 (Table S1; Ryder 2013). The name, meaning 'by, or close to, the wood', is a good indicator of woodland survival, although three ploughs are also recorded indicating a substantial arable component to the holding. In the Domesday demesne (manorial land retained for the private use of a feudal lord) there was one plough and four villeins (feudal surf or tenant owing labour to the manor) had half a plough. There was also 150 acres (61 ha) of pasture. The bog sits just within land owned by the farm at Gorwell, which is also mentioned in Domesday ('Gorwilla') and was a grange of Dunkeswell Abbey (Young 1955).

\section{Greenway: palaeoecological results}

The shallow core spans approximately $40 \%$ of the Holocene (up to the 18 th century rise in Pinus) with no obvious hiatus, suggesting a low peat accumulation rate $\left(0.2 \mathrm{~mm} \mathrm{a}^{-1}\right)$. The low rate of accumulation restricts the temporal resolution of vegetation changes in the diagram, but the record does span the critical Late Bronze Age/Early Iron Age transition.

Tree pollen dominates GW1 and the abundance of Corylus suggests that it probably formed part of an open woodland canopy that stood around the mire with Quercus, Ulmus and Tilia reflecting the presence of mixed oak woodland on the dry valley slope. The first major change in the diagram at the GW1/GW2a boundary is an increase in Cyperaceae and wetland types, suggesting the expansion of wet meadow and flushes (Fig. 6). This occurred simultaneously with a decline in tree species, which opened up the woodland canopy in favour of Pteridium and heliophilous climbing species such as Lonicera and Hedera. The dominance of relatively open woodland is reflected by the presence of heliophilous species and there are fluctuations in the ratio of woodland pollen to grass and herbaceous pollen, which may indicate small-scale woodland clearance followed by woodland regeneration on site. Minor fluctuations continue in the diagram until a major change at the GW2/GW3 boundary when grass pollen increases and woodland species decrease dramatically along with a 50\% fall in organic matter and a rise in charcoal. This is interpreted as a dramatic change in the vegetation with associated clay in-wash rather than a hiatus due to the lack of a dramatic change of other pollen types and the time interval between the radiocarbon dates (460-1270 years), which is typical of the site accumulation rate. It is therefore suggested that this change indicates the rapid clearance of adjacent woodland upslope of the site. However, woodland taxa remain at over $40 \%$ TLP, which suggests cleared areas were small. The clearance is accompanied by the appearance of Avena-Triticum-type and Hordeum-type pollen, suggesting that wheat or oats and possibly barley were being grown in the new clearing. However, Hordeum-type pollen includes the pollen of wild grasses such as Glyceria, which could have been growing on the mire and flushes (Andersen 1978; Edwards 1998). The presence of significant amounts of Corylus, Quercus, Betula, Tilia, Ulmus and Fagus with herbs of woodland margins suggests that substantial stands of woodland persisted on the nearby steep valley 

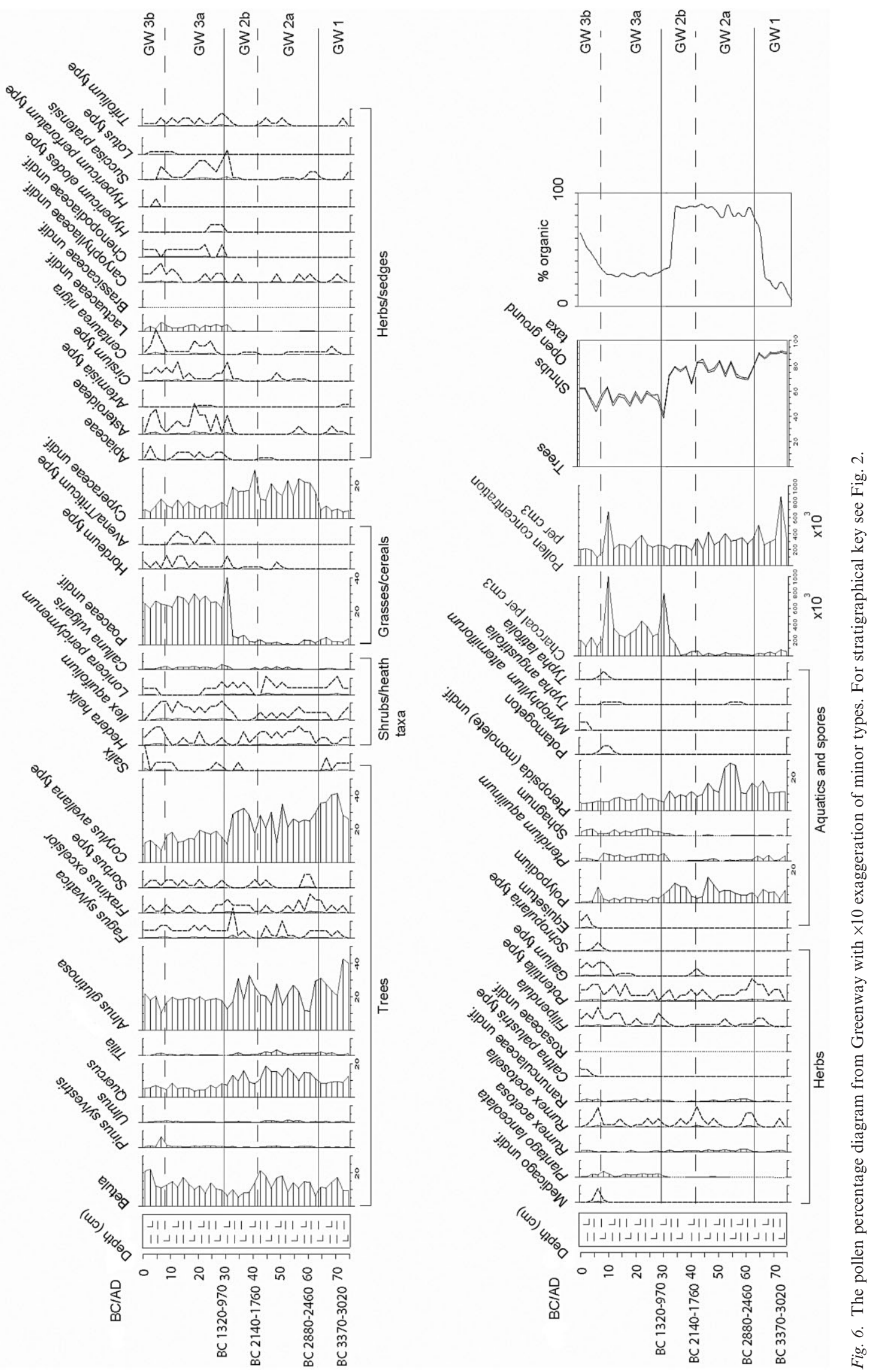
slope (probably over $50 \%$ of the extra-local area) even after the clearance episode. Cereal pollen disappears from the diagram at $19 \mathrm{~cm}$ but the trace amounts of later cereal pollen (at $13 \mathrm{~cm}$ ) suggest that the later phase of cultivation also took place on a small scale in a predominantly pastoral landscape. The disappearance of Avena-Triticum-type pollen occurs simultaneously with a rise in pine and some woodland species and a decline in heath types (GW3a/GW3b). However, significant amounts of woodland pollen (62\% TLP) remain at the top of the pollen diagram, suggesting that woodland and heath remained an important component of the landscape into the historical period.

\section{Greenway: archaeological and historical results}

The archaeology recorded in the HER within a 2-km radius of the mire relates to iron-working (Table $\mathrm{S} 1$ ), and no new archaeological sites were discovered adjacent to the mire. The nearest site is $500 \mathrm{~m}$ to the north at Greenway hamlet. Here, a possible iron pit and smelting site is recorded and large quantities of slag, a fragment of a furnace bottom and ore nodules. The mire is situated within an irregular shaped field system, which may represent piecemeal enclosure of the valley side. The curved shape of the field system (aratral curve) also indicates that this area was subject to ploughing and therefore arable cultivation in the Medieval Period. Greenway, mentioned in Domesday as 'Grenowei' (Williams \& Martin 1991) and held by Walter of Douai, is a manor with land for six ploughs, 10 acres of meadow and pasture and 10 acres of scrub woodland. Later listed as a park (in this instance meaning enclosed land), Greenway was given by William de Mohun to Newnham Abbey (Polwhele 1793-1806; Ryder 2013).

The typology of the field system is indicative of ley cultivation and convertible husbandry (Rippon et al. 2006) and the tithe appointment field names, Starve Acre, Oat Moor and Raven Moor, all suggest arable cultivation. Starve Acre suggests agriculturally less productive land, and Ravens is typically a representation of starvation often used to indicate poorer conditions in a rotational system (Field 1993; Ryder 2013).

\section{Middleton: palaeoecological results}

Although there are no age reversals, the basal date of $4070 \pm 70$ BP (Table 2) is much older than the dates above and this suggests that a hiatus occurred on site some time after $2880-2460$ BC. This is supported by changes in the stratigraphy, LOI and pollen concentration. The pollen diagram has been divided into three zones with the further subzones of MD2 (Fig. 7). Woodland taxa dominate MD1 with mixed deciduous woodland on the drier valley slopes whereas Ilex and Lonicera represent clearings or the woodland fringe and Alnus suggests nearby wet woodland. There is a rapid decline in tree species at the MD1/MD2a boundary and it is suggested that this reflects a hiatus in peat deposition. Above the hiatus the high percentage of grass and herb pollen suggests that pasture and heath dominated a largely open landscape. Species-rich meadow and rough pasture are also suggested by the presence of Lactuceae, Ranunculus, Rumex and other herb taxa, which are sensitive to heavy grazing (Groenman-van-Waateringe 1993). Cereal pollen (Avena-Triticum) first appears in MD2a coincident with a further decline in woodland species such as Quercus, Betula, Corylus and Alnus at the MD2a/ MD2b boundary. The sporadic nature of the Hordeum type and Avena-Triticum type curves in the diagram suggests that two or more separate phases (in MD2a and MD2b) of cereal cultivation took place in the immediate vicinity of the bog. There is a rise in open ground taxa at the same time as the decline in cereal pollen in zone MD3. Tree species always exceed $15 \%$ TLP of the dry-land taxa with Corylus and Quercus persisting as pockets of woodland in the medieval landscape. Quercus, Betula, Alnus and Corylus and other woodland types begin to recover after $35 \mathrm{~cm}$ (top of MD2b). Grass values dip, Hordeum type declines and Avena-Triticum species are no longer recorded in the diagram, suggesting that scrub woodland started to infringe onto previously cultivated or grassy areas. Heath species such as Calluna, Ericales and Pteridium continue to be well represented in the diagram, which suggests that heathland was maintained. The Pinus rise at $15 \mathrm{~cm}$ depth at the MD2c/3 boundary occurs simultaneously with a fall in woodland and heath types, however, the continuing presence of Fagus, Fraxinus, Sorbus, Ilex and Hedera indicate scrub woodland and possibly layed hedgerows in the vicinity - a traditional practice and common today in the area, which may reflect the deliberate enclosure of common land for pasture during the 19th century.

\section{Middleton: archaeological and historical results}

Fourteen archaeological sites occur within the survey area (Table S1). Rectangular earthworks and ridged cultivation occur close to the farmhouse, which is called Middleton Barton and is late 16th century in origin. The area to the immediate west of the sample site is recorded as a Deer Park (Fig. 3), and other entries include records of clay-pits and gravel-pits (Table S1). Strip field systems and lobe-shaped fields at Knowle and Hole Farms and Bolham indicate cultivation. Fieldwork suggests that the earthworks are the remains of the Medieval settlement of Middleton. The name Middleton or 'Middle town' may refer to the enclosure of woodland between the two Domesday manors of Bolham and Hole (Holne) although its date of establishment is unknown. The fact that Middleton does not appear in Domesday is not conclusive because it may 


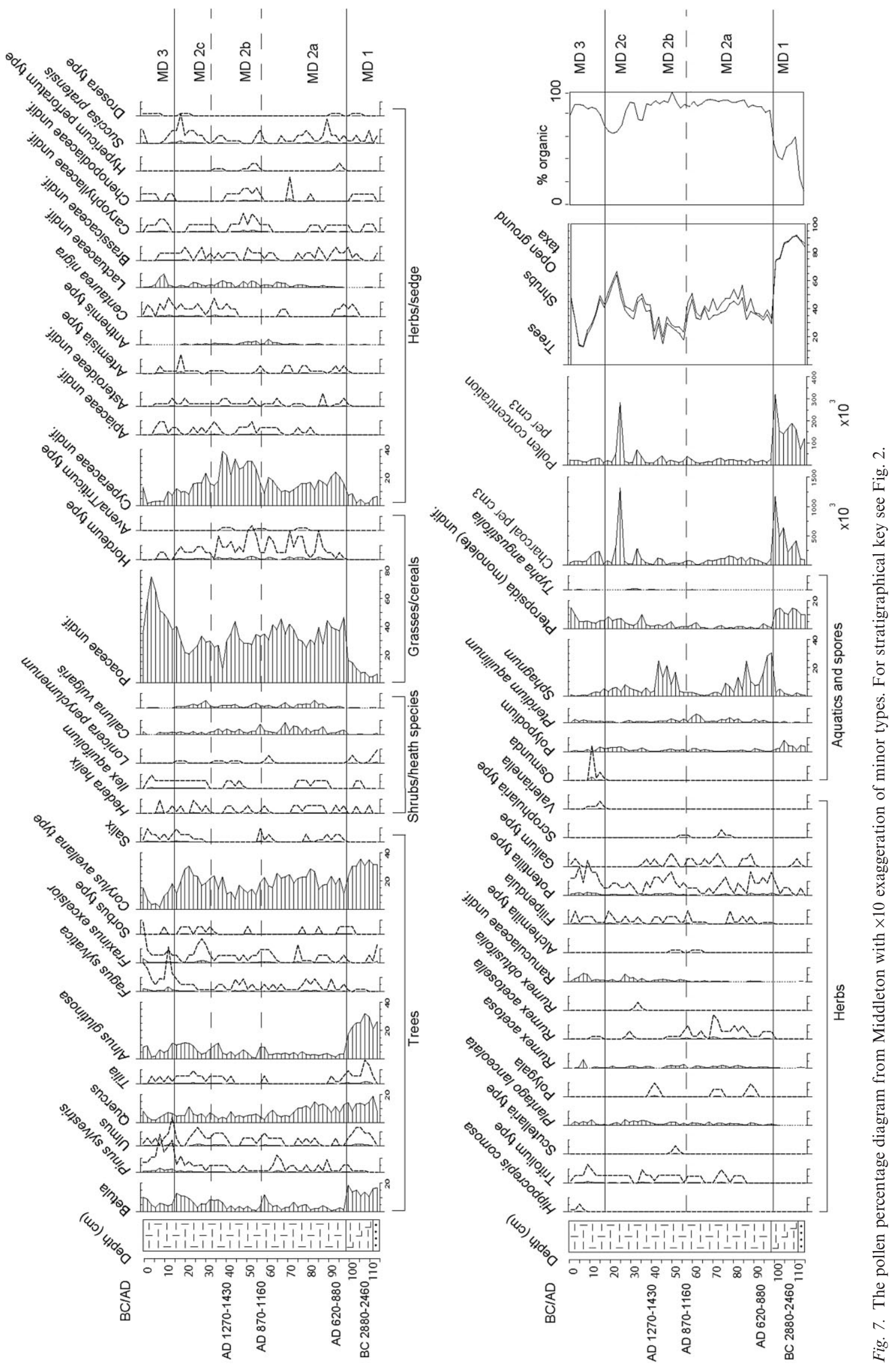


have been a satellite holding belonging to a larger manor nearby and thus would be recorded under that entry. In summary, the evidence is of mixed farming with the survival of some woodland from the early 11 th century AD to the Post-Medieval period.

\section{Bolham: palaeoecological results}

Not unusually for a flood-plain site the AMS dating revealed an age reversal in zones $\mathrm{BH} 1-\mathrm{BH} 2 \mathrm{~b}$ at Bolham (Table 2). The dates coincide with a rapid fall in LOI values indicating probable contamination by old carbon from in-washed organic matter (Fig. 8). A hiatus in the pollen diagram at the base of $\mathrm{BH} 3 \mathrm{~b}$ and an acceleration in the rate of sediment accumulation coincides with a band of peat. The dates suggest that organic clay accumulated slowly over several millennia until a hiatus event dated to shortly before AD 10201285 causing peat to grow until a further in-wash of old organic matter at AD 1455-175, which was followed by the rapid accumulation of organic clay until the $c$. AD 1800 Pinus rise.

The pollen diagram has been divided into four zones with reduced TLP counts (250 grains) for the lowest levels. However, both the pollen and the dates suggest that the accumulation at the site occurred over most of the Holocene but with several abrupt changes in the accumulation rate and probable hiatuses. The dominance of grass and herbaceous species and Alnus at the bottom of the diagram indicates that the landscape was open with wet woodland on the valley floor. The appearance of Alnus at 7055-6480 BC (up to 4\%) is early but is in accordance with other sites in southern England and appears to mark its patchy spread up river valleys in advance of rising sea levels (Brown 1988; Bennett \& Birks 1990). Other tree species are present, including Quercus, Pinus and Corylus, which suggests that there were woodland pockets in the landscape. The rise in tree pollen at the beginning of zone $\mathrm{BH} 2 \mathrm{a}$ suggests that woodland expanded on the drier slopes surrounding the flood-plain. Corylus dominates zone $\mathrm{BH} 2 \mathrm{~b}$ although the presence of sedge and grass species suggests that the landscape remained partly open An increase in Fraxinus (a secondary woodland species noted for poor pollen dispersion (Scaife 1988)), Tilia and heath types may reflect woodland disturbance close to the pollen in BW3a. Tilia suffers from poor pollen production and dispersal (Huntley \& Birks 1983) and so it is likely that its presence above trace levels $(>1 \%)$ indicates that it was a significant component of the mid-Holocene woodland. The trace amounts of Hordeum type pollen in $\mathrm{BH} 2 \mathrm{~b}$ and $\mathrm{BH} 3$ but no AvenaTriticum type pollen suggests that it reflects wild grass on the wet meadow rather than arable cultivation. Heather and bracken are present in significant quantities in zones $\mathrm{BH} 3 \mathrm{a}-\mathrm{BH} 3 \mathrm{~d}$, suggesting that heath was also a component of the local landscape accompanied by meadow and a woodland into the post-Medieval period. There is a hiatus in the pollen diagram and in the stratigraphy at $75 \mathrm{~cm}$, which, given the nature of the site, is probably due to erosion by floodwaters. Above this hiatus the dominance of grass and herbaceous types in the diagram indicated by a rise in Lactuceae, Compositae, Brassicaceae, and Potentilla suggests species-rich wet meadow. Woodland species are also represented, suggesting that deciduous woodland continued to be present in the landscape. The rise in Alnus, Corylus and Betula at the $\mathrm{BH} 3 \mathrm{c} / \mathrm{BH} 3 \mathrm{~d}$ boundary suggests that scrub woodland colonized areas of abandoned grassland followed by Corylus, Fraxinus and possibly rowan (Sorbus type), whilst Tilia and Ulmus grew on free-draining soils. The lack of any Avena/Triticum pollen in the diagram suggests that the landscape was predominantly pastoral with substantial pockets of woodland remaining in drier areas $(>50 \%$ TLP AP).

\section{Bolham: archaeological and historical results}

The HER records tracks, undated buildings and clay pits close to the flood-plain mire (Table S1). Earthworks also suggest that there were mills nearby at Batten's Farm and at Bolham. There are two records of possible cultivation terraces, one of which is situated approximately $400 \mathrm{~m}$ to the southeast of the pollen site; the other is situated $800 \mathrm{~m}$ to the northeast. The manor of Bolham Water is also mentioned in Domesday under an entry for 'Boleham' as reproduced here: 'Otelin holds Bolham Water from Baldwin. Almaer held it in TRE [in the time of King Edward] and it paid geld for 2 hides. There is land for 6 ploughs. In demesne are 2 ploughs and 2 slaves; and 2 villeins and 6 bordars with 2 ploughs. There are 24 acres of meadow, pasture 1 league long and half a league broad and woodland half a league long and 1 furlong broad. Formerly 20 s now it is worth 35 s.' (as transcribed by Williams \& Martin 1991).

This remarkably detailed 11th century AD record provides us with a semiquantitative estimate of the arable land (defined by ploughs), meadow, pasture, and significant woodland of some value surrounding the pollen site. More specifically this suggests $0.6-2 \mathrm{~km}^{2}$ of arable land (one plough being equated with $40-120$ acres or $16-48 \mathrm{ha}$ ), $0.09 \mathrm{~km}^{2}$ of meadow, $2.9 \mathrm{~km}^{2}$ of pasture and $0.2 \mathrm{~km}^{2}$ of woodland. In total this amounts to between 3.8 and $5.2 \mathrm{~km}^{2}$. This can also be taken to imply management, such as coppicing and/or timber production. Other documentary records also mention the manor of Bolham due to its association with the Abbey of Dunkeswell from AD 1215 onwards (Style \& Style 1998), providing evidence of continuity of land use into the High Medieval period. 

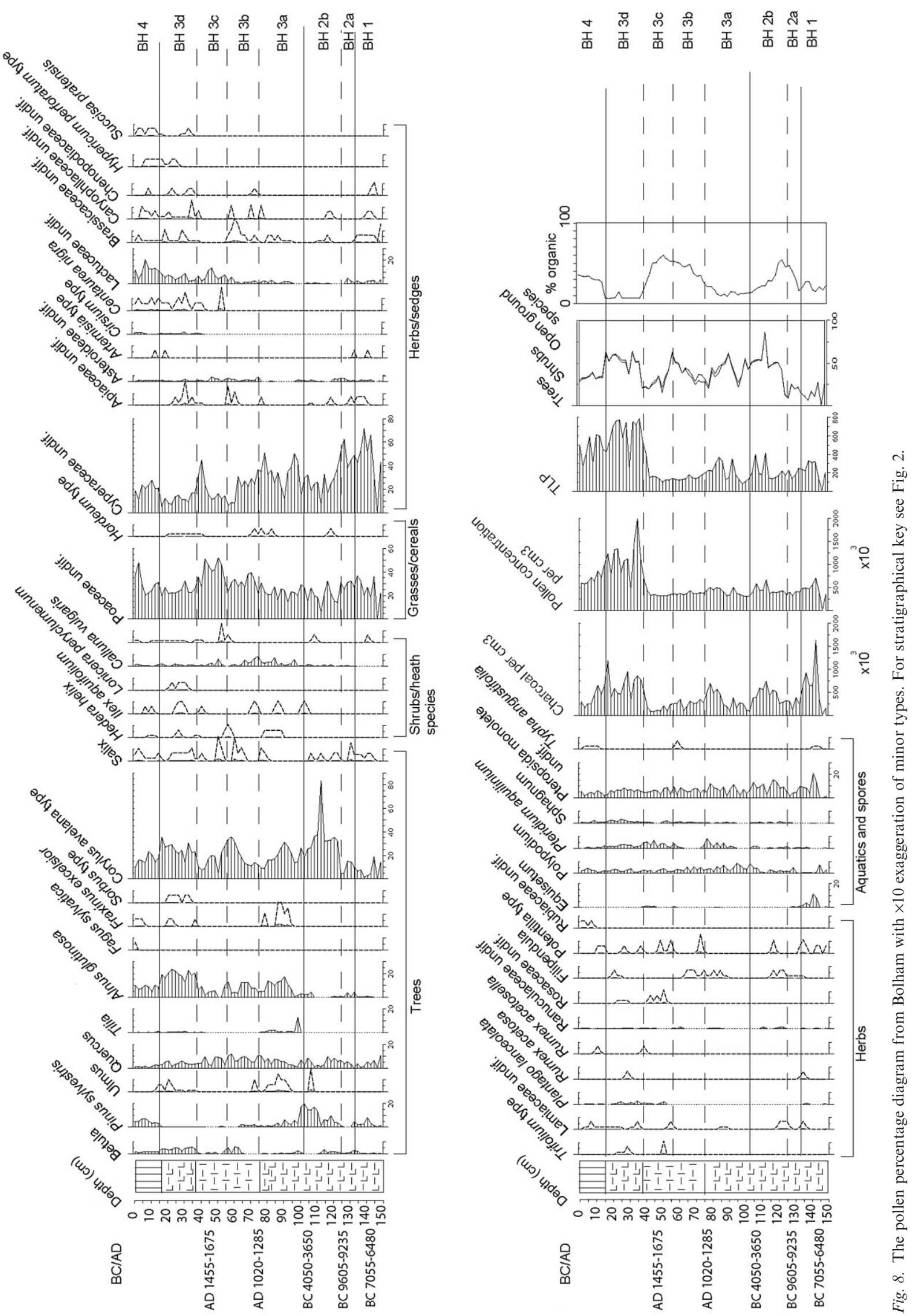


\section{Place name evidence}

Abundant place name evidence suggests the existence of a large quantity of woodland persisting into the Medieval period (from which most rural place names date; Gover et al. 1932). These include Bywood, Highwood Farm, Ridgewood Farm, Stentwood Farm and Longwood Farm. There are also a large number of place names that include reference to particular tree taxa such as Ashculm, Straight Ash Farm (Fraxinus), Aller Farm, Blackaller Farm, Allerbeare Farm (Alnus), Holmwood Farm (Ilex), Willow Farm (Salix), Oaklands Copse (Quercus), Beechwood Farm (Fagus) and names referring to both woodland and field elements such as Woodhayes $(\times 2)$ and pasture including Greenway and Leigh Cross, Hidonfields Farm and Fields Farm. In contrast there are very few place names that refer to arable agriculture with one possible exception on the plateau (Barleycombe Farm) and indirectly Lammaslands nearby (Lammas is the Anglo-Saxon festival of the first harvest of the year). Several place names reflect peat cutting such as the many 'turbaries'. A common element in Blackdown field names is ' $\mathrm{rag}$ ', meaning land that can be converted into pasture within rougher pasture or woodland (Ryder 2013). Whilst there are many complications and biases in place and field name data (Higham \& Ryan 2011) the heavy preponderance of woodland over agricultural names is likely to be a reflection of Medieval land use and landscape character (Rippon 2012).

\section{Discussion}

The pollen record from Bolham provides the earliest evidence of landscape change from open grassland with a small woodland component in the early Mesolithic, to Pinus-Corylus woodland in the middle to later Mesolithic. The occurrence of Poaceae and herbaceous taxa in the diagram suggests that open, damp vegetation covered the valley floor at Bolham in the later Mesolithic and into the early Neolithic. The persistently high Poaceae and Cyperaceae at Bolham reflects the open nature of the flood-plain and clearings associated with the river, palaeochannels and probably tree-throws on thin alluvial soils (Brown 1997, 1999). In contrast, the landscape at Greenway is dominated by deciduous woodland in the later Neolithic and Bronze Age. The Middleton diagram also indicates that a predominantly wooded landscape existed in the late Neolithic and early Bronze Age (c. 3300-2600 BC). There is no clear 'elm decline' at Bolham as Ulmus and the correspondence of Ulmus with other deciduous trees, including Tilia, suggests that it could just be a component of Neolithic-Bronze Age clearance rather than disease related. However, the dating problems at the site make this a provisional observation. Evidence of cereal cultivation from the
British Isles and from macrofossil data suggests that although at some sites initial cereal cultivation coincided or even preceded the elm decline between 4000 and 3800 BC (Parker et al. 2002; Brown 2007), this was rare, with the major expansion of cereal cultivation not taking place until later in the Middle Bronze Age (Stevens \& Fuller 2012). However, no cereal pollen appears in the Bolham diagram at this level and the archaeological evidence suggests that activity was limited and highly localized within the Blackdown Hills at this time. Hembury Hillfort (Fig. 1) provides the nearest archaeological evidence of early Neolithic settlement and evidence of agricultural activity including carbonized cereal chaff, and saddle querns (Liddell 1930, 1931, 1932, 1935; Fox 1964; Todd 1984). Recent re-dating of the Hembury evidence (Whittle et al. 2011) has demonstrated that the construction of the Neolithic causewayed enclosure took place in the 37 th century BC and its occupation appears to have continued for around 100-200 years thereafter. Given the lack of water on the plateau at Hembury it is likely that grazing was taking place in the valley below the hillfort (due to the high water requirements of cattle), and this is consistent with the evidence of pastoral evidence at Bolham. Further evidence of early Neolithic activity on the eastern Blackdown Hills plateau, at Membury, includes pits containing charred emmer/ spelt grain and hazelnuts, a possible causewayed enclosure (Tingle 2006) and a probable enclosure on the coast at High Peak dated to 3945-3515 BC (Whittle et al. 2011). Taken together, the lack of generalized vegetation impact but localized small-scale palynological and archaeological evidence support Stevens \& Fuller's (2012) suggestion of a limited and possibly unsuccessful early Neolithic introduction of farming with wild resource exploitation remaining dominant.

At Greenway, Late Bronze Age woodland clearance appears synchronous with a rise in charcoal. To the south of the Blackdown Hills at Castle Hill, Feniton, excavations have revealed extensive Bronze age activity through the discovery of multiple Bronze Age flint scatters, a Middle-Bronze Age field system, and several farmsteads. A further Middle and Late Bronze Age enclosed settlement was excavated east of Honiton (Fitzpatrick et al. 1999), whilst aerial reconnaissance has provided evidence that the lowland river valleys were a focus of human activity in the later Prehistoric period (Griffith 1984; Caseldine et al. 2000). The fieldwork undertaken at Bywood has also revealed possible Prehistoric field systems, whereas field systems and droveways of Middle Bronze Age date have also been recorded in rescue excavations to the east of Exeter (Pearce et al. 2011). Early Bronze Age activity is recorded by the barrow cemeteries and flint scatters on the plateau. The pollen analysis at Greenway indicates Late Bronze Age human activity in the Luppitt valley 


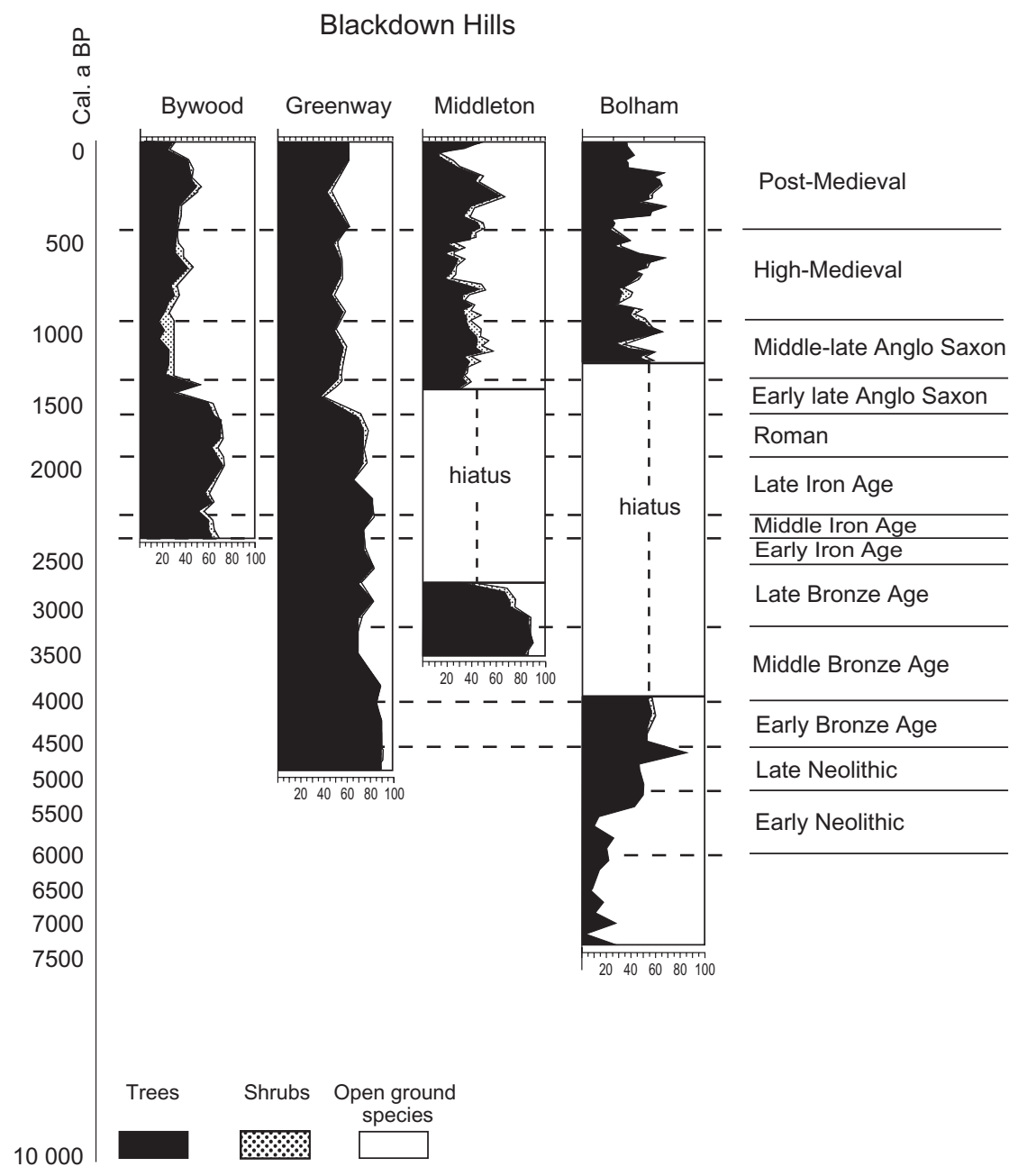

Fig. 9. A comparison of the summary pollen diagrams from the four sites with local archaeological periods. and is consistent with the provisional identification of a field-system. Due to the poor soils it is likely that the former field structures survived because it was not economically viable to improve them. Within historic times local farmers believed that the fields on this western side of the Blackdown Hills had traditionally been given to the poor, as the land was of poorer agricultural quality (Ryder 2013). The Bronze Age clearance at Greenway occurs later than in other diagrams from lowland Devon (Fyfe et al. 2003) and it is possible that the clearance reflects either a hiatus or the delayed expansion of agriculture onto more marginal areas of East Devon.

The Iron Age to Romano-British record from these sites is limited as neither Middleton nor Bolham records this period due to hiatuses (Fig. 9). However, the Greenway and Bywood diagrams suggest that significant arable cultivation started in the Iron Age. Interpolation suggests Triticum or Avena were cultivated at Greenway c. 680-60 BC. At Bywood, clearance followed by cereal cultivation is dated to $200 \mathrm{BC}$ to AD 40. At Bywood, the Late Iron Age clearance of sheltered areas of the hill-crest would have provided flat, open spaces for cereal cultivation with exposed areas used as pasture. The archaeological evidence also supports the concept of increased activity during the Iron Age in the Blackdown Hills (Todd 1984). The Iron Age hillforts of Dumpdon, Hembury and sites to the west (Woodbury Castle) and north (Castle Neroche) and over 14 hillslope enclosures provide evidence of later prehistoric agricultural activity. Comparatively few enclosures in East Devon have been excavated: of these some have been shown to be Bronze Age (Fitzpatrick et al. 1999) although the majority dates to the later Iron Age and Romano-British periods. At Hembury the sheer size and scale of the earthwork ramparts suggest that it was a major focus of activity within the landscape 600-400 BC (Liddell 1935; Todd 1984, 1992).

After the later Iron Age there are only subtle changes in the Greenway and Bywood diagrams, suggesting a degree of woodland continuity in the Blackdown Hills landscape. There appears to be minimal change in the two pollen spectra that span the Romano-British 
period and although the resolution is poor in both cases the data provide little evidence that the Roman military occupation had significant impact on the wider environment of the Blackdown Hills although it may have had localized impacts. Localized impacts may also explain an apparent contradiction with the substantial archaeological evidence of Roman activity in the area (Griffith 1997). This includes the Fosse Way and Exeter-Dorchester Roman roads, early Roman forts at Woodbury Farm (Axminster), Pomeroy Wood (Honiton, Fitzpatrick et al. 1999) and Waddon Hill, possible late Roman forts at Seaton and Holcombe (Holbrook 1987) and a probable port at Seaton or Axmouth (Weddell et al. 1993; Holbrook et al. 2008). Other Roman sites in the area include the villas at Holcombe (Uplyme) and Whitestaunton. Archaeological evidence also suggests that the Roman army occupied the hillfort at Hembury AD 50-60 as quantities of pottery and iron slag were found during excavations of the Roman quarters (Liddell 1935; Todd 1992). Firstcentury AD military pottery was also found in the extraction pit for a furnace at Sweetlands Farm, Upottery (Griffith \& Weddell 1996). The archaeology indicates that Romano-British iron smelting also took place at Bywood and possible reflection of this in the mire is the unusually high charcoal values $\left(1500 \times 10^{3}\right.$ fragments $\mathrm{cm}^{-3}$ ) in the Roman to Medieval levels (BW2a-BW2b). Along with the uninterrupted presence of Corylus and Quercus pollen through these zones, this may reflect the management by coppicing of the woodland in order to maintain a fuel supply. Support for this association comes from the rarity of woodland persistence elsewhere in southern England, with the exception of areas where fuel was required for pottery kilns, such as the pollen diagrams from core areas of the ancient and ornamental woodlands in the New Forest that show a persistence of woodland cover despite major changes in species composition (Grant \& Edwards 2008; Grant et al. 2009a, 2014). Steep valleys on Exmoor have produced charcoal evidence of woodland management from iron-working slag heaps (Juleff 2000). The evidence for stability and continuity in the diagrams suggests there was only localized impact on the rural landscape during both the Romano-British and Antique (early post-Roman) periods. This is not surprising considering the remote and secluded nature of the Blackdown Hills, which were probably the focus of less attention than the easily accessible and more fertile land of the lowland river valleys to the east and west. More research is needed to investigate the scale and extent of the iron-working, but the evidence for vegetation continuity at Bywood and Greenway suggests that it took place within a partly wooded agricultural landscape, which the local population farmed and managed.

At Bywood and Greenway there is strong evidence of further deforestation during the early Medieval period, probably between the 6th and 8th centuries AD. This has been observed elsewhere in southern England and is associated with settlement nucleation (Rippon 2010) and extensive open field systems have been mapped in seven parishes on the more fertile eastern border zone of the Blackdown Hills (Carter 2008). However, from all four diagrams there is little evidence for subsequent landscape change during the Medieval period and the historical evidence is that changes were small scale; on a farm or estate basis, and occurred in a piecemeal fashion (Turner 2007). Management continued in this fashion until the sweeping Acts of Parliamentary Enclosure during the early 19 th century that affected the northern plateaus of the Blackdown Hills. The palynological evidence suggests that open grassland with a scrub woodland component continued to dominate the local landscape at all four sites supporting an agricultural system similar to that on Greater Exmoor (Fyfe et al. 2004a). However, there are some subtle differences amongst the four diagrams. For example at Bywood and Greenway cereal cultivation continued throughout the Medieval period but at Middleton cereal pollen only appears twice in the diagram, at AD 730-1020 and AD 1270-1430, and there is no evidence of cereal cultivation at Bolham. This is supported by documentary evidence that suggests that the land around Middleton was used for grazing in the 12th and 13th centuries, evidenced in field system morphology by a number of droveways. At Bywood, cultivation probably took place on the hilltop just above the mire and so the mire is very close to the area of cultivation and ideally placed to receive both airborne pollen and pollen in-wash from the hill top. The location of the pollen sampling sites at Greenway and Middleton may be situated further away from the most likely areas of cultivation and this may be reflected by the discontinuous cereal pollen curves in both diagrams. The valley floor at Bolham is more suited to grazing than arable cultivation due to the heavy clay soil and flooding. Therefore, if Medieval cereal cultivation occurred at Bolham it would probably have taken place on the drier valley slopes beyond the RSAP and this may explain why there is no cereal pollen in the diagram. However, this heterogeneity is also a function of localized human landscape management as has been noted from a similar study on Dartmoor (Fyfe \& Woodbridge 2012).

The pollen records reported here suggest that later Medieval woodland regeneration occurred at all four sites starting AD 1280-1410 at Bywood but later at the other sites. This pattern of local variation reflects the Medieval history of the area with small land-holdings persisting under the relatively small Cistercian abbeys at Forde, Newnham and Dunkeswell. In the Middleton and Bolham diagrams woodland regenerated on open grassland in the 15 th and 16th centuries AD and archaeological evidence for this exists in the 
deserted/shrunken medieval settlements at Wortheal, Williambeer and Weston, as well as sites surveyed as part of this study such as Jacob's City and Bushy Knapp and Buckerell Knap (Ryder 2013; Fig. 1). The regeneration at Greenway occurred much later and appears to coincide with a second phase of regeneration at Bywood. The rise in Pinus estimated at $c$. AD 1750-1800 is accompanied by a decline in woodland at all four sites. This suggests the Post-Medieval decline in woodland at all four sites was a result of a further intake of scrub woodland, or in some cases heathland, as a result of the late enclosure that characterizes the upper land in this area as opposed to the ancient enclosure in the valleys.

The incomplete woodland clearance of the landscape may be a result of the unique topographical and edaphic character of the western-central Blackdown Hills - a plateau dissected by steep, narrow valleys with waterlogged valley-sides and floors and acidic sandy and flint-rich soils. At all four sites the soils are Hense Association (Findlay et al. 1984), which are characteristically humified peaty soils permanently waterlogged and poorly drained so not suited to arable farming. Trees, in particular Quercus, Corylus and Betula, remain significant at $30 \%$ or over in all the diagrams, which suggests that woodland continued to be an important resource within the open landscape, providing a source of charcoal for the iron-working industry, other secondary products and woodland pasture (Hiley 1954; Rackham 1980; Ralston 1999; Rippon 2012). The diagrams also confirm that heathland was a more important component of the landscape than it is today as only small remnants survive today on the plateau at Ashculme and Dunkeswell Turbaries (Fig. 1) and that the square field patterns of the plateau date from 19th century enclosure and the conversion of heath to pasture.

The contrast between this western-central area of the Blackdown Hills in the counties of Devon and Dorset, and the historical and archaeological evidence of more complete clearance and extensive arable farming in the eastern border area in Somerset, suggests that the county boundary, which was only established in the Late Medieval to Post-Medieval period, may reflect a deeper and long-lived eco-cultural boundary.

\section{Regional landscape homogeneity and the concept of the 'pays'}

The landscape history described here exhibits significant contrasts with other areas in Devon and Cornwall, including the Exe Valley (Fyfe et al. 2003), the South Devon coast (Cove 2007), mid-Devon (Caseldine et al. 2000), Exmoor (Straker \& Crabtree 1995), the Greater Exmoor area (Fyfe et al. 2004a, b; Fyfe 2006; Rippon et al. 2006), Dartmoor (Caseldine \& Hatton 1994; West et al. 1996; Amesbury et al. 2008; Fyfe et al. 2008; Fyfe 2012: Fyfe \& Woodbridge 2012) and Bodmin Moor
(Brown 1977; Gearey et al. 2000). Table S2 lists welldated sites and the minimum \%AP along with the most significant period of tree reduction. Although \%AP is known not to be linearly related to vegetation openness, it is correlated (Sugita et al. 1999) and probably underestimates openness for open and semi-open land cover types (Fyfe et al. 2010). More sophisticated analysis using quantitative reconstructions of land cover (sensu Sugita 2007) is prevented by the limited chronological resolution of these sites as well as well as the difficulty in estimating relevant source areas of pollen from small mires as opposed to lakes (Bunting et al. 2004). All the above areas show some clearance in the Neolithic and landscape-scale clearance during the Bronze Age with eventually very little woodland surviving (Table S2). Moving further east across southern England (Fig. 1) we can divide the records into three groups; firstly those areas where there was landscapescale woodland clearance in the Bronze Age (parts of the Somerset Levels, the Isle of Wight, and the Weald), which in some cases may have been near total deforestation (e.g. parts of Cranborne Chase), a second group with some prehistoric clearance but more complete clearance in the Romano-British and Medieval periods (parts of the Somerset Levels, the Dorset Heaths and Romney Marsh) and lastly a group showing some deforestation in the Bronze Age and later in the Medieval period but the maintenance of woodland cover with changes in species composition (parts of the New Forest and the Dorset Heaths). The Blackdown Hills sites fall in between these last two categories and are superficially closest to the record from the Ancient and Ornamental Woodlands in the New Forest (e.g. Church Moor and Barrow Moor), which are believed to have never been clear-felled (Grant et al. 2009a, in press). A similar pattern is found in parts of northern European plain such as northern France (Cyprien et al. 2004), the Ardennes (Lefevre et al. 1993) and eastern Denmark (Hannon et al. 2000). Interestingly, Table S2 also reveals no obvious reflection of whether British sites lay inside or outside Medieval 'Forests and Chases'. This is not surprising as historical evidence suggests that these Royal preserves contained no more woodland than the average for England. reflecting foremost their legal status rather than landscape character (Langton \& Jones 2010). However, if landscapes survived partially wooded into the post-Roman period and through the Anglo-Saxon period, the complex legal and cultural management of these Royal Forests allowed multiple and competing land uses to co-exist and in some cases prevented whole-scale deforestation (Langton \& Jones 2010). This is definitely the case with the New Forest in Hampshire (Tubbs 2001) but also may have been a factor in and around the 'Forest of Naroche', which occupied what is today the northern part of the Blackdown Hills and is known to have been pre- 
Norman in origin (Page 1911) despite its omission from the Domesday Survey (Rackham 2000). Wooded landscape elements (copses, hillside woodlands, orchards) formed part of the irregular pattern of small enclosed fields or 'closes' (Rippon et al. 2013) characteristic of the Medieval historic landscape of the Blackdown pays, which was then protected by small ecclesiastical houses and the establishment of a Royal Forest in part of the area. The combination of fragmented ecclesiastical landholdings and the establishment of Royal or elite Forests and Chases is an important element in the subregional landscape history of England and other parts of France and NW Europe and is a major cultural element in the formation of pays or distinctive ecocultural regions. Pays as subregional areas of distinctive landscape history result from a diachronic interaction of physical elements (relief, geology/mineral resources, soils) and these cultural elements, which include isolation, land tenure and resource exploitation. The persistence and importance of these environmental factors is in this region, as many others in Europe, was probably focused through the early Medieval period (Rippon 2010; Williamson 2013). An integral part of the identification of pays is also the idea that people become attached to these places through history and there is some element of subregional identity or expressions of shared cultural and natural heritage (Olwig 2007). The documentary studies that show persistent tenurial relationships, common typonyms and distinctive post-Medieval folklore (Franklin 2006; Ryder 2013) suggest that such a regional identity existed in the Blackdown Hills at least from the Medieval period onwards. The implication of a growing realisation that these distinctive eco-cultural regions, or pays are both identifiable and based fundamentally on natural environmental factors is that palaeoecology has a valuable role in examining their history.

\section{Conclusions}

The similarity in size of the four sites analysed, their proximity and common coverage of at least the Bronze and post-Roman periods enables partial comparison of local vegetation trajectories. Despite relatively poor temporal resolution this provides ecological histories for what would otherwise be a blank area of Europe partially redressing the inherent spatial bias of palaeoecological data.

Only one of the sites (Bolham) shows evidence of woodland clearance in the Neolithic, suggesting that agricultural activity was of limited extent and had little impact on the landscape whereas the three sites that cover the Bronze Age all show deforestation. From the location of the sites it is almost certain that this was preferential clearance of the plateau. Archaeological field survey discovered enclosures and field systems adjacent to one of the sites (Bywood), although timeequivalence cannot be demonstrated without excavation. Two of the sites suggest an expansion of arable farming in the Iron Age, which is supported by the archaeological evidence of a substantial population associated with local hillforts and enclosed sites, which may have played an important role in the storage of agricultural surpluses (Van de Noort et al. 2007).

From the two sites that span the Romano-British period there is no evidence of significant deforestation but a persistence of a patchy pattern of a partially cultivated and grazed plateau with woodland on the steep valley slopes. The occurrence of iron-working evidence (both slag and charcoal) at two of the sites strongly suggests that this may have been the result of the management of the woodland for fuel. Recent changes such as the loss of heathland and the rise in birch following the cessation of coppicing are reflected in the pollen diagrams.

The application of palaeoecological analyses with targeted archaeological survey and documentary analyses has shown how the ecological history of the Blackdown Hills is closely related to its cultural history within a distinctive topographic and edaphic context including restricted Neolithic incursion, partial Bronze Age deforestation, Iron Age land use intensification and Romano-British and Medieval woodland management associated with iron-working. This also includes evidence of land use intensification in the Anglo-Saxon period and the emergence of an eco-cultural boundary approximating to the present county boundary.

Although there are differences amongst the diagrams, as would be expected from small sites reflecting local landscape management, the differences are less than with other subregions in SW England such as Dartmoor, Exmoor or the Somerset Levels. It is also apparent that the Blackdown Hills may be one of the few areas in England, along with the New Forest, where patches of woodland on valley sides have persisted throughout the Holocene due to a combination of poor soils, rural industry, Medieval woodland management and the creation of Royal Forests. It can therefore be suggested that the Blackdown Hills represents a distinctive region qualifying the area as a pay or eco-cultural region, as also proposed by Rippon (2012) from archaeological data. This is reflected in the modern historic landscape characterization of the area, which is now being used in planning (Clark et al. 2004).

This study also supports the contention that there are Prehistoric to Medieval origins of the subregional landscapes that remain a distinctive element of northern Europe today, and that palaeoecological analyses can contribute to our understanding of the development of eco-cultural regions or pays because from the Iron Age onwards regional cultural variation has itself largely been a consequence of environmental factors - local climate, soils and hydrology. 
Acknowledgements. - The fieldwork for this paper was undertaken by volunteers who with the research staff were supported financially by the UK Heritage Lottery Fund. The authors must thank Steve Reed (Exeter Archaeology) and Bill Horner (Devon County Council) for assistance with the project. We must also thank Kenneth Farmer and all landowners for access to the sites. The authors thank the reviewers for their valuable comments.

\section{References}

Aaby, B. \& Berglund, B. E. 1986: Characterization of peat and lake deposits. In Berglund, B. E. (ed.): Handbook of Holocene Palaeoecology and Palaeohydrology, 231-246. Wiley, Chichester.

Aalbersberg, G. 1999: The alluvial fringes of the Somerset levels. $\mathrm{Ph} . \mathrm{D}$. thesis, University of Exeter, $250 \mathrm{pp}$.

Amesbury, M. J., Charman, D. J., Fyfe, R. M., Langdon, P. L. \& West, S. 2008: Bronze Age upland settlement decline in southwest England: testing the climatic change hypothesis. Journal of Archaeological Science 35, 87-98.

Andersen, S. T. 1978: Identification of wild grass and cereal pollen. Danmarks Geologiske Undersogelse, Årbog 1978, 69-92.

Andrew, R. 1984: A Practical Pollen Guide to the British Flora. Quaternary Research Association, Technical Guide No. 1, 139 pp. Quaternary Research Association, Cambridge.

Beckett, S. C. \& Hibbert, F. A. 1979: Vegetational change and the influence of prehistoric man in the Somerset Levels. New Phytologist 83, 577-600.

Bennett, K. D. 1994: Annotated catalogue of pollen and pteridophyte spore types. Unpublished report, Department of Plant Sciences, University of Cambridge.

Bennett, K. D. \& Birks, H. J. B. 1990: Postglacial history of alder (Alnus glutinosa (L.) Gaertn.) in the British Isles. Journal of Quaternary Science 5, 123-133.

Berridge, P. J. 1985: The Mesolithic sites in the Yarty Valley. Proceedings of Devon Archaeological Society 43, 1-21.

Berridge, P. J. 1986: Mesolithic evidence from Hembury. Proceedings of Devon Archaeological Society 44, 163-166.

Brown, A. G. 1988: The palaeoecology of Alnus (alder) and the postglacial history of floodplain vegetation: pollen percentage and influx data from the West Midlands, U.K. New Phytologist 110, 425-436.

Brown, A. G. 1997: Clearances and clearings: deforestation in Mesolithic/Neolithic Britain. Oxford Journal of Archaeology 16, 133-146.

Brown, A. G. 1999: Characterizing prehistoric lowland environments using local pollen assemblages. Quaternary Proceedings 7, 585594.

Brown, A. G., Hawken, S., Griffith, F., Franklin, L. \& Hawkins, C. 2004: Landscape archaeology and public participation: the community landscape project, Devon, UK. Public Archaeology 3, 217226.

Brown, A. P. 2007: Dating the onset of cereal cultivation in Britain and Ireland: the evidence from charred cereal grains. Antiquity 81, $1042-1052$.

Bunting, M. J. 2008: Pollen in wetlands: using simulations of pollen dispersal and deposition to better interpret the pollen signal. Biodiversity and Conservation 17, 2079-2096.

Bunting, M. J., Gaillard, M.-J., Sugita, S., Middleton, R. \& Broström, A. 2004: Vegetation structure and pollen source area. The Holocene 14, 651-660.

Carter, R. W. 2008: Former medieval open fields in the eastern Blackdowns. Proceedings of the Somerset Archaeology and Natural History Society 152, 153-164.

Caseldine, C. J. \& Hatton, J. M. 1994: Into the mists? Thoughts on the prehistoric and historic environmental history of Dartmoor. Devon Archaeological Society Proceedings 52, 35-48.

Caseldine, C. J., Coles, B. J., Griffith, F. M. \& Hatton, J. M. 2000: Conservation or change? Human influence on the Mid-Devon landscape. In Nicholson, R. A. \& O'Connor T. P. (eds.): People as Agents of Environmental Change, 60-70. Association of Environmental Archaeologists Symposium No. 16. Oxbow Books, Oxford.
Clark, J., Darlington, J. \& Fairclough, G. 2004: Using Historic Landscape Characterisation. 120 pp. English Heritage and Lancashire County Council, London.

Cove, M. 2007: Ancient forests of the South Devon coast: 8,000 years of changing vegetation determined by pollen analysis. Transactions of the Devonshire Association for the Advancement for Science 139, 293-331.

Cunliffe, B. 1993: Wessex to AD 1000. A Regional History of England. 388 pp. Longman, London.

Cyprien, A. -L., Visset, L. \& Carcaud, N. 2004: Evolution of vegetation landscapes during the Holocene in the central and downstream Loire basin (Western France). Vegetation History and Archaeobotany 13, 181-196.

De la Blache, P. V. 1918: Principles of Human Geography, (translated edition 1926). 511 pp. H. Holt and Co., New York.

Edwards, K. J. 1998: Detection of human impact on the natural environment: palynological views. In Bayley, J. (ed.): Science in Archaeology: An Agenda for the Future, 69-89. English Heritage, London.

Field, J. 1993: A History of English Field-names. 320 pp. Longman, London \& New York.

Findlay, D. C., Colbourne, G. J. N., Cope, D. W., Harrod, T. R., Hogan, D. V. \& Staines, S. T. 1984: Soils and their use in South West England. Soil Survey of England and Wales Bulletin, No. 14., 210 pp. Soil Survey of Great Britain, Lawes Agricultural Trust, Harpenden.

Fitzpatrick, A. P., Butterworth, C. A. \& Grove, J. 1999: Prehistoric and Roman sites in East Devon: The A30 Honiton to Exeter Improvement DBFO Scheme, 1996-1999. WA Report 16, 443 pp. Wessex Archaeology, Salisbury.

Fox, A. 1964: South-West England. 254 pp. Thames \& Hudson, London.

Franklin, L. 2006: Imagined landscapes: archaeology, perception and folklore in the study of Medieval Devon. In Turner, S. (ed.): Medieval Devon and Cornwall: Shaping an Ancient Countryside, 144 161. Windgather Press, Macclesfield.

French, C., Lewis, H., Allen, M., Green, M., Scaife, R. \& Gardiner, J. 2007: Prehistoric landscape development in the upper Allen valley, Cranborne Chase, Dorset. 400 pp. McDonald Institute for Archaeological Research, Cambridge.

Fyfe, R., Brown, A. G. \& Coles, J. 2003: Mesolithic to Bronze Age vegetation change and human activity in the Exe Valley, Devon, UK. Proceedings of the Prehistoric Society 69, 161-182.

Fyfe, R., Roberts, N. \& Woodbridge, J. 2010: A pollen-based pseudobiomisation approach to anthropogenic land-cover change. The Holocene 20, 1165-1171.

Fyfe, R. M. 2006: Palaeoenvironmental perspectives on Medieval landscape development. In Turner, S. (ed.): Medieval Devon and Cornwall: Shaping an Ancient Countryside, 10-23. Windgather Press, Macclesfield.

Fyfe, R. M. 2012: Bronze Age landscape dynamics: spatially detailed pollen analyses from a ceremonial complex. Journal of Archaeological Science 39, 2764-2773.

Fyfe, R. M. \& Woodbridge, J. 2012: Differences in time and space in upland vegetation patterning: analysis from pollen data from Dartmoor, UK. Landscape Ecology 27, 745-760.

Fyfe, R. M., Brown, A. G. \& Rippon, S. 2004b: Mid- to lateHolocene vegetation history of Greater Exmoor, UK: estimating the spatial extent of human-induced vegetation change. Vegetation History and Archaeobotany 12, 215-232.

Fyfe, R. M., Brown, A. G. \& Rippon, S. J. 2004a: Characterising the late prehistoric, 'Romano-British' and medieval landscape, and dating the emergence of a regionally distinct agricultural system in South West Britain. Journal of Archaeological Science 31, 16991714.

Fyfe, R. M., Brück, J., Johnston, R., Lewis, H., Roland, T. \& Wickstead, H. 2008: Historical context and chronology of a Bronze Age enclosure on Dartmoor, UK. Journal of Archaeological Science 35, 2250-2261.

Gearey, B., Charman, D. \& Kent, M. 2000: Palaeoecological evidence for the prehistoric settlement of Bodmin Moor, Cornwall, Southwest England. Part I: the status of woodland and early human impacts. Journal of Archaeological Science 27, 423-438. 
Gover, J. E. B., Mawer, A. \& Stenton, F. M. 1932: The Place Names of Devon. Part II. 754 pp. The Place names Society, Nottingham. Available at: http://www.nottingham.ac.uk/ins/placenamesociety/ index.aspx.

Grant, M. J. \& Edwards, M. E. 2008: Conserving idealised landscapes: past history, public perception and future management in the New Forest (UK). Vegetation History and Archaeobotany 17, 551-562.

Grant, M. J., Barber, K. E. \& Hughes, P. D. M. 2009a: True ancient woodland? - 10,000 years of continuous woodland cover at Mark Ash Wood, New Forest. In Briant, R. M., Bates, M. R., Hosfield, R. T. \& Wenban-Smith, F. F. (eds.): The Quaternary of the Solent Basin and West Sussex Raised Beaches, 215-233. Quaternary Research Association, London.

Grant, M. J., Barber, K. E. \& Hughes, P. D. M. 2009b: Early to mid-Holocene vegetation-fire interactions and responses to climatic change at Cranes Moor, New Forest. In Briant, R. M., Bates, M. R., Hosfield, R. T. \& Wenban-Smith, F. F. (eds.): The Quaternary of the Solent Basin and West Sussex Raised Beaches, 198-206. Quaternary Research Association, London.

Grant, M. J., Hughes, P. D. M. \& Barber, K. E. 2014: Climatic influence upon early to mid-Holocene fire regimes within temperate woodlands: a multi-proxy reconstruction from the New Forest, Southern England. Journal of Quaternary Science. 29, 175-188.

Griffith, F. M. 1984: Aerial reconnaissance in 1984: A preliminary report and the discovery of a hillfort. Proceedings of the Devon Archaeological Society 42, 23-38.

Griffith, F. M. 1988: Devon's Past: An Aerial View. 128pp. Exeter, Devon Books.

Griffith, F. M. 1994: Changing perceptions of the context of prehistoric Dartmoor. Proceedings of the Devon Archaeological Society $52,85-100$

Griffith, F. M. 1997: Developments in the study of Roman military sites in South West England. In Groenman van Waateringe, W. (ed.): Roman Frontier Studies 1995: Proceedings of the XVIth International Congress of Roman Frontier Studies, 361-369. Oxbow Monograph 91, Oxford.

Griffith, F. M. \& Weddell, P. J. 1996: Ironworking in the Blackdown Hills: results of recent survey. In Newman, P. (ed.): The Archaeology of Mining and Metallurgy in South West Britain, 27-34. Peak District Mines Historical Society, Matlock Bath.

Grime, J. P., Hodgson, J. G. \& Hunt, R. 1988: Comparative Plant Ecology: a Functional Approach to Common British Species. 752 pp. Unwin Hyman, London.

Grimm, E. 1988: Data analysis and display. In Huntley, B. \& Webb, T. (eds.): Vegetation History, 43-76. Kluwer, Dordrecht.

Groenman-van-Waateringe, W. 1993: The effects of grazing on the pollen production of grasses. Vegetation History and Archaeobotany 2, 157-162.

Hannon, G., Bradshaw, R. \& Emborg, J. 2000: 6000 years of forest dynamics in Suserup Skov, a seminatural Danish woodland. Global Ecology and Biogeography 9, 101-114.

Hatton, J. M. \& Caseldine, C. J. 1991: Vegetation change and land use history during the first millennium AD at Aller Farm, East Devon. Proceedings of the Devon Archaeological Society 49, 107114

Hawkins, C. 2005: Vegetation history and land use change over the past 10,000 years in three study areas of lowland Devon: the Blackdown Hills, the Clyst valley and the Hartland Peninsula. Ph.D. thesis, University of Exeter, $198 \mathrm{pp}$.

Heiri, O., Lotter, A. \& Lemcke, G. 2001: Loss on ignition as a method for estimating organic and carbonate content in sediments: reproducibility and comparability of results. Journal of Paleolimnology 25, 101-110.

Hellman, S., Gaillard, M.-J., Bumting, J. M. \& Mazier, F. 2009: Estimating the relevant source area of pollen in the past cultural landscapes of southern Sweden - a forward modelling approach. Review of Palaeobotany and Palynology 153, 259-271.

Higham, N. J. \& Ryan, M. J. 2011: Place-names, Language and the Anglo-Saxon Landscape. 256 pp. The Boydell Press, Woodbridge.

Hiley, W. E. 1954: Woodland Management. 463 pp. Faber and Faber, London.
Holbrook, N. 1987: Trial excavations at Honeyditches, Seaton and the nature of Roman occupation. Proceedings of the Devon Archaeological Society 45, 59-74.

Holbrook, N., Davenport, P., Evans, D., King, A., Leach, P. \& Webster, C. 2008: Roman. In Webster, C. J. (ed.): Archaeology of South West England, 151-162. South West Archaeological Research Framework Resource Assessment and Research Agenda. Somerset County Council, Taunton.

Huntley, B. \& Birks, H. J. B. 1983: An Atlas of Past and Present Pollen Maps for Europe: 0-13000 years ago. 667 pp. Cambridge University Press, Cambridge.

Jacobsen, G. L. \& Bradshaw, R. H. W. 1980: The selection of sites for palaeovegetational study. Quaternary Research 16, 80-96.

Juleff, G. 2000: New radiocarbon dates for iron-working sites on Exmoor. Historical Metallurgy Society News 44, 3-4.

Langton, J. \& Jones, G. 2010: Deconstructing and reconstructing the forests: some preliminary matters. In Langton, J. \& Jones, G. (eds.): Forests and Chases of Medieval England and Wales c. 1000c.1500. Towards a Survey and Analysis, 1-13. St Johns College Research Centre, Oxford.

Lefevre, D., Heim, J., Gilot, E. \& Mouthon, J. 1993: Évolution des environnements sédimentaires et biologiques à l'Holocène dans la plaine alluviale de la Meuse (Ardennes, France): premiers résultats. Quaternaire 4, 17-30.

Liddell, D. M. 1930: Report on the excavations at Hembury Hillfort. Proceedings of the Devon Archaeological Society I, 1-24.

Liddell, D. M. 1931: Report on the excavations at Hembury Hillfort. Proceedings of the Devon Archaeological Society I, 90-120.

Liddell, D. M. 1932: Report on the excavations at Hembury Hillfort. Proceedings of the Devon Archaeological Society I, 162-190.

Liddell, D. M. 1935: Report on the excavations at Hembury Hillfort. Proceedings of the Devon Archaeological Society II, 135-178.

Moore, P. D., Webb, J. A. \& Collinson, M. E. 1991: Pollen Analysis. 216 pp. Blackwells, Oxford.

Odgaard, B. V. 1992: The fire history of Danish heathland areas as reflected by pollen and charred particles in lake sediments. The Holocene 2, 218-226.

Olwig, K. R. 2007: The practice of landscape 'conventions' and the just landscape: the case of the European Landscape Convention. Landscape Research 32, 579-594.

Overland, A. \& Hjelle, K. L. 2009: From forest to open pastures and fields: cultural landscape development in western Norway inferred from two pollen records representing different spatial scales of vegetation. Vegetation History and Archaeobotany 18 , 459-476.

Page, W. 1911: Victoria County History of Somerset. Vol. 2. 171 pp. Victoria County Histories, London.

Parker, A. G., Goudie, A. S., Anderson, D. E., Robinson, M. A. \& Bonsall, C. 2002: A review of the mid-Holocene Ulmus decline in the British Isles. Progress in Physical Geography 26, 1-45.

Pearce, P., Steinmetzer, M. \& Quinnell, H. 2011: An Early Neolithic pit alignment, Grooved Ware and Bronze Age field boundaries at the former Royal Naval Stores Depot, Old Rydon Lane, Exeter. Proceedings of the Devon Archaeological Society 69, 23-52.

Polwhele, R. 1793-1806, 1977: The History of Devonshire in Three Volumes. 238 pp. Kohler and Coombes, Exeter.

Rackham, O. 1980: Ancient Woodland: Its History, Vegetation and Uses in England. 402 pp. Edward Arnold, London.

Rackham, O. 2000: The History of the Countryside. 448 pp. Phoenix, London.

Ralston, I. B. M. 1999: The Iron age: aspects of the human communities and their environments. Quaternary Proceedings 7, $501-512$.

Rippon, S. 2010: Landscape change during the 'long eighth century' in southern England. In Higham, N. \& Ryan, M. J. (eds.): The Landscape of Anglo-Saxon England, 39-64. Boydell, Woodbridge.

Rippon, S. 2012: Making Sense of a Historic Landscape. 416 pp. Oxford University Press, Oxford.

Rippon, S., Smart, C., Pears, B. \& Flemming, F. 2013: The Fields of Britannia: continuity and discontinuity in the Pays and regions of Roman Britain. Landscapes 14, 33-53.

Rippon, S. J., Fyfe, R. M. \& Brown, A. G. 2006: Beyond villages and open fields: the origins and development of a historic landscape 
characterized by dispersed settlement in South-West England. Medieval Archaeology 50, 31-70.

Ryder, L. 2013: Change and Continuity: A study in the Historic Landscape of Devon. 256 pp. Windgather Press, Oxford.

Scaife, R. G. 1987: The late-Devensian and Flandrian vegetation of the Isle of Wight. In Barber, K. E. (ed.): Wessex and the Isle of Wight Field Guide, 156-180. Quaternary Research Association, London.

Scaife, R. G. 1988: The Ulmus decline in the pollen record of South East England and its relationship to early agriculture. In Jones, M. (ed.): Archaeology and the Flora of the British Isles, 21-33. Oxford University Committee for Archaeology Monograph, 14, University of Oxford, Oxford.

Seagrief, S. C. 1959: Pollen diagrams from southern England: Wareham, Dorset and Nursling, Hampshire. New Phytologist 58, 316-325.

Silvester, R. J. \& Bidwell, P. T. 1984: A Roman site at Woodbury, Axminster. Proceedings of the Devon Archaeological Society 42, $33-57$.

Skinner, C. \& Brown, A. G. 1999: Mid-Holocene vegetation diversity in eastern Cumbria. Journal of Biogeography 26, 45-54.

Stanes, R. G. F. \& Edwards, R. A. 1993: Devonshire Batts: the whetstone mining industry and community of Blackborough, in the Blackdown Hills (with an appendix on the geology of the Whetstone Beds). Report and Transactions of the Devonshire Association for the Advancement of Science 125, 71-112.

Stevens, C. J. \& Fuller, D. Q. 2012: Did Neolithic farming fail? The case for a Bronze Age agricultural revolution in the British Isles. Antiquity 86, 707-722.

Straker, V. \& Crabtree, K. 1995: Palaeoenvironmental studies on Exmoor: past research and future potential. In Binding, H. (ed.): The Changing Face of Exmoor, 43-51. Exmoor Books, Tiverton.

Stuiver, M. \& Reimer, P. J. 1993: Extended ${ }^{14} \mathrm{C}$ data base and revised CALIB $3.0{ }^{14} \mathrm{C}$ age calibration program. Radiocarbon 35, 215-230.

Style, C. \& Style, O.-L. 1998: A History of Bolham Manor, Family Faces Series. 140 pp. Private Publication for Brian Turstan, Bolham Mill.

Sugita, S. 1994: Pollen representation of vegetation in quaternary sediments: theory and method in patchy vegetation. Journal of Ecology 82, 881-897.

Sugita, S. 2007: Theory of quantitative reconstruction of vegetation II: all you need is LOVE. The Holocene 17, 243-257.

Sugita, S., Gaillard, M.-J. \& Broström, A. 1999: Landscape openness and pollen records: a simulation approach. The Holocene 9, 409421.

Summerson, H. 1985: Crown Pleas of the Devon Eyre of 1238. Devon and Cornwall Record Society, New Series 28, 1-3.

Tingle, M. 2006: Excavations of a possible causewayed enclosure and Roman site at Membury 1986 and 1994-2000. Proceedings of the Devon Archaeological Society 64, 1-52.

Todd, M. 1984: Excavations at Hembury (Devon), 1980-83: a summary report. Antiquaries Journal 64, 187-199.

Todd, M. 1987: The Southwest to AD 1000. A Regional History of England. 338 pp. Longman, London.

Todd, M. 1992: The hillfort of Dumpdon. Proceedings of the Devon Archaeological Society 50, 47-52.

Tubbs, C. 2001: The New Forest: History, Ecology and Conservation. $450 \mathrm{pp}$. New Forest Ninth Centenary Trust, Hampshire.

Turner, S. 2005: Devon Historic Landscape Characterisation. Phase 1 Report. Report prepared for Devon County Council Historic Environment Service \& English Heritage, 94 pp. County Hall, Exeter.

Turner, S. 2007: Ancient country: the historic character of rural Devon. Devon Archaeological Society Occasional Paper 20, 220 pp.

Van de Noort, R., Henry Chapman, H. \& Collis, J. (eds.) 2007: Sutton Common - the excavation of an Iron Age 'marsh-fort'. Council for British Archaeology, Research Report 154, 235 pp.

Waller, M., Long, A. J., Long, D. \& Innes, J. B. 1999: Regional vegetation history of Wallend Marsh and Romney Marsh. Quaternary Science Review 18, 1419-1444.
Waller, M. P. \& Schofield, J. E. 2007: Mid to late Holocene vegetation and land use in the Weald of south-eastern England: multiple pollen profiles from the Rye area. Vegetation History and Archaeobotany 16, 367-384.

Waton, P. V. \& Barber, K. E. 1987: Rimsmoor, Dorset: biostratigraphy and chronology of an infilled doline. In Barber, K. E. (ed.): Wessex and the Isle of Wight Field Guide, 75-80. Quaternary Research Association, London.

Webster, C. J. 2008: Archaeology of South West England. South West Archaeological Research Framework Resource Assessment and Research Agenda. 371 pp. Somerset County Council, Taunton.

Weddell, P. J., Reed, S. J. \& Simpson, S. J. 1993: Excavations of the Exeter-Dorchester Roan road at the River Yarty and the Roman fort ditch and settlement site at Woodbury, near Axminster. Proceedings of the Devon Archaeological Society 51, 33-133.

West, S., Charman, D. \& Grattan, J. 1996: Palaeoenvironmental investigations at Tor Royal, Central Dartmoor. In Charman, D. J., Newman, R. M. \& Croot, D. G. (eds.): Devon and East Cornwall Field Guide, 97-100. Quaternary Research Association, London.

Whittle, A., Healy, F. \& Bayliss, A. 2011: Gathering Time: Dating the Early Neolithic Enclosures of Southern Britain and Ireland. 992 pp. Oxbow Books, Oxford.

Whittle, A. W. R. 1977: The earlier neolithic of Southern England and its Continental Background. British Archaeological Reports, International Series S35, 23-47.

Wiecken, J. 2004: Iron working in the Blackdown Hills - a report on two slag mounds (feature 3 and 4) on Bywood Farm/Dunkeswell and a general discussion of the distribution of ironworking. Unpublished report for the Community Landscapes Project, University of Exeter, Exeter.

Williams, A. \& Martin, G. H. (eds.) 1991: The Devonshire Domesday. 153 pp. Alecto Historical Editions, London.

Williamson, T. 2013: Environment, Society and Landscape in Early Medieval England. 270 pp. The Boydell Press, Suffolk.

Young, J. 1955: Devon \& Cornwall Record Society New Series Volume 1. Devon Monastic Lands: Calendar of Particulars for Grants 15361558 Torquay. 180 pp. Torquay Times \& Devon Press Ltd., Torquay.

\section{Supporting Information}

Additional Supporting Information may be found in the online version of this article at the publisher's web-site:

Table S1. Sites recorded on the SMR for a $2 \mathrm{~km}$ area around each mire by permission of Devon County Council.

Table S2. Selected pollen data from recognized 'historical landscapes' in southern England. Minimum levels of tree pollen $(\% \mathrm{AP})$ recorded in Holocene levels of pollen diagrams in southern England that extend from the Mid-Holocene to at least the Roman period with the probable exception of Wareham. Abbreviations: $\mathrm{N}=$ Neolithic; $\mathrm{BA}=$ Bronze Age; IA = Iron Age; $\mathrm{RB}=$ Romano-British; Med. = Medieval; $\mathrm{PM}=$ Post-Medieval. Sites in bold are covered or surrounded by woodland today. All area and site names in italics were certainly, or probably, within 'forests and chases' (largely Royal Forest) during the Medieval to early Post-Medieval period as mapped by Langton \& Jones (2010). 